\title{
Transcriptional responses and embryotoxic effects induced by pyrene and methylpyrene in Japanese medaka (Oryzias latipes) early life stages exposed to spiked sediments
}

Iris Barjhoux, Jérôme Cachot ${ }^{\bowtie}$, Patrice Gonzalez, Hélène Budzinski, Karyn Le Menach, Laure Landi, Bénédicte Morin and Magalie Baudrimont

Univ. Bordeaux, EPOC UMR 5805, avenue des Facultés, 33405 Talence Cedex, France

\footnotetext{
${ }^{\bowtie}$ Corresponding author: Dr Jérôme Cachot

E-mail contact: j.cachot@epoc.u-bordeaux1.fr

Phone: +33 (0)540003830

Fax: $+33(0) 540002267$
} 


\section{Abstract}

2 Japanese medaka (Oryzias latipes) embryos were exposed to sediments spiked to environmental

3 concentrations (300 and 3,000 ng/g dry weight) of pyrene (Pyr) and methylpyrene (MePyr) throughout

4 their development. Embryotoxicity, teratogenicity and transcriptional responses (qRT-PCR) were

5 analyzed in embryos and newly hatched larvae. The genotoxicity of the two polycyclic aromatic

6 hydrocarbons (PAHs) was also tested in prolarvae using the comet assay. Exposure to each compound

7 had a clear impact on embryonic development and resulted in many teratogenic effects, including

8 cardiovascular injuries, reduced absorption of yolk sac reserves and jaw and spinal deformities.

9 Interestingly, the overall toxic effects of Pyr and MePyr considerably overlapped those induced following

10 dioxin exposure. qRT-PCR analysis revealed the transcriptional induction of genes involved in

11 mitochondrial energetic metabolism (coxI), xenobiotic biotransformation (cypla) and cell cycle

12 regulation (wnt 1 ) by the two PAHs. MePyr also activated cell cycle arrest ( $p 53)$, oxidative DNA damage

13 repair $(\operatorname{ogg} 1)$ and retinoid-mediated (raldh2 and $\operatorname{rar} 1)$ gene transcription. Moreover, DNA damage was

14 found to increase in a concentration-dependent manner following Pyr and MePyr exposure. The lack of

15 significant genotoxic effect in comparison to control might be the consequence of the efficient onset of

16 DNA damage repair mechanisms as suggested by $\operatorname{ogg} 1$ gene transcription upregulation. Results reported

17 in the present study have brought new insight into the modes of action of Pyr and the effects of MePyr

18 exposure have been investigated in fish ELS for the first time.

20 Keywords: PAH spiked sediments, fish early life stage, gene expression, embryotoxicity, teratogenicity,

21 genotoxicity 


\section{1. Introduction}

2 Polycyclic aromatic hydrocardons (PAHs) are ubiquitous contaminants that are primarily introduced into

3 the environment through anthropogenic activities such as the incomplete combustion of organic matter,

4 fossil fuels, oil and wood. Firstly released in the aquatic environment through land-based runoff, 5 industrial and urban effluents and atmospheric deposition, they get trapped in sediments due to their 6 hydrophobic properties (Dupree and Ahrens 2007; Ineris 2006). Since many fish species use sediments as spawning substrate, PAHs can represent a long-term threat for aquatic ecosystems due to their persistence and their ability to pass through biological membranes and to accumulate in organisms.

9 For the past few decades, many studies have demonstrated the high sensitivity of fish early life stages 10 (ELS) to PAH exposure (e.g.: Li et al. 2011; Cachot et al. 2007; Farwell et al. 2006; Rhodes et al, 2005; 11 Incardona et al. 2004; Carls et al. 1999). A wide range of developmental defects have been reported following exposure to PAHs including pericardial and yolk sac edema, jaw deformities, spinal curvature and various cardiovascular injuries. Among PAHs, certain congeners proved to be AhR (aryl hydrocarbon receptor)-agonists and teratogens with symptoms highly comparable to those of the blue sac disease (BSD) syndrome induced by 2,3,7,8-tetrachlorodibenzo- $p$-dioxin (TCDD) exposure, suggesting similar modes of action (Barron et al. 2004; Incardona et al. 2004; Brinkworth et al. 2003; Billiard et al. 1999). However, unlike dioxins, PAHs can be rapidly metabolized by vertebrates (Billiard et al. 2008). Indeed, PAHs have the particularity to induce their own metabolization by activating the transcription of genes encoding for phase I drug/xenobiotic cytochrome P450 enzymes, phase II conjugation enzymes and phase III transporters through AhR pathway activation (Feng et al. 2013; Denison and Heath-Pagliuso 1998). Paradoxically, it is nowadays well established that a variety of unstable and reactive intermediates, sometimes more toxic than the parent compound, as well as reactive oxygen species (ROS) can be generated during PAH metabolism (Shimada 2006; Morel et al. 1999). Consequently, PAHs can exert their developmental toxicity involving a wide range of mechanisms dependent on their chemical structure and rate of metabolization. For instance, Incardona et al. $(2004 ; 2005)$ reported that primary toxicity of phenanthrene and dibenzothiophene was AhR-independent in zebrafish (Danio rerio) embryos.In contrast to these congeners but similarly to TCDD, the defects in cardiac function and morphogenesis induced by 
1 benz[a]anthracene proved to be AhR2-dependent and CYP1A-independent in zebrafish embryos

2 (Incardona et al. 2006).

3 The AhR pathway is involved in various signaling pathways covering multiple physiological aspects such

4 as cell proliferation and differentiation, apoptosis, gene regulation and angiogenesis (Feng et al. 2013).

5 Thus, many AhR-dependent toxic effects of PAHs are likely to result from continuous and inappropriate

6 expression of specific genes in susceptible cells (Denison and Heath-Pagliuso 1998).

7 Moreover, several enzymes involved in the metabolism of PAHs also participate in the metabolism of

8 retinoids such as, CYP1A, UDP-glucoronosyl transferase and glutathione-S-transferase (Boily et al.

9 2004). Retinoids are crucial for many vital processes such as growth and development. Both excess and 10 deficiency of retinoids can result in embryotoxicity and/or teratogenicity in vertebrates (Novak et al. 11 2008). Alterations in retinoids have also been associated with exposure to PAHs and the embryotoxic and teratogenic potencies of those compounds make them suspected to interfere with retinoid signaling

13 (Noval et al. 2008; Rolland 2000).

14 Despite careful analyses and consistent findings across species, the precise mechanisms leading to PAH15 associated malformations and sub-lethal effects in fish ELS are still unclear. In the present study, we 16 propose a modified version of the medaka embryo-larval assay with sediment-contact exposure (MELAc) 17 (Barjhoux et al. 2012; Vicquelin et al. 2011) to simultaneously analyze the phenotypic and molecular effects of pyrene (Pyr) and methylpyrene (MePyr) in medaka (Oryzias latipes) ELS. Pyr has been found at very high concentrations in sediments, sometimes exceeding $10 \mu \mathrm{g} / \mathrm{g}$ of sediment (see Table 1) from areas heavily impacted by PAHs. Indeed, Pyr is often amongst the most abundant of PAHs in sites affected by creosote or pyrogenic inputs (Nagy et al. 2013; Kimbrough and Dickhut 2006; Wang et al. 2001). Moreover, Pyr has been reported to greatly accumulate and to be efficiently metabolized by phase I and phase II enzymes in fish ELS (Honkanen et al. 2008; Petersen and Kristensen 1998). In spite of its weak potency as an AhR agonist (Barron et al. 2004), Pyr exposure induced developmental defects in $D$. rerio embryos that considerably overlap those reported for TCDD (Incardona et al. 2006; 2005). These studies also highlighted the crucial role of CYP1A enzyme activity in the underlying mechanism of Pyr toxicity. MePyr is also present in sediments from PAH affected areas (Notar et al. 2001). MePyr proved to be bioaccumulable in various aquatic species including teleost fish (Pancirov and Brown 1977) and is 
1 considered to be genotoxic and a potent carcinogen in mammals (Glatt et al. 2008; Monien et al. 2008),

2 but to our knowledge, no study is available on the effects of MePyr in fish ELS.

3 To characterize the potential impact of environmental concentrations of these PAHs in fish ELS, medaka

4 embryos were exposed to Pyr or MePyr-spiked sediments at 300 (C1) and 3,000 (C2) ng/g dry weight

5 (dw) throughout their whole embryonic development. Several non-invasive markers of acute and

6 sublethal toxicity were recorded during the course of the exposure. In parallel, qRT-PCR analysis of

7 transcription levels of target genes was carried out in embryos and newly hatched larvae in order to obtain

8 an overview of the modulations in metabolic pathways following Pyr and MePyr exposure. Finally, the 9 potential genotoxicity of Pyr and MePyr was investigated in 2-day old larvae using the comet assay.

\section{Material and Methods}

\subsection{Experimental design}

Japanese medaka (Oryzias latipes) embryos of the CAB strain were purchased from GIS Amagen (Gifsur-Yvette, France). Embryos at one day post-fertilization (dpf) were exposed to five different spiked sediments: a control group at $0 \mathrm{ng} / \mathrm{g}$ dw of sediment; a Pyr-C1 group at $300 \mathrm{ng} \mathrm{Pyr} / \mathrm{g} \mathrm{dw}$; a MePyr-C1 group at $300 \mathrm{ng} \mathrm{MePyr} / \mathrm{g} \mathrm{dw}$; a Pyr-C2 group at 3,000 ng Pyr/g dw; and a MePyr-C2 group at 3,000 ng $\mathrm{MePyr} / \mathrm{g} \mathrm{dw}$ (nominal concentrations). Each treatment consisted of six replicates of 70 embryos each. The first three replicates of each treatment were dedicated to sampling at the embryonic stage (T7) and the three remaining ones kept for larval stage samplings (T9). Medaka embryos remained in direct contact with the sediment up to sampling time, i.e. for $7 \mathrm{dpf}(\mathrm{T} 7)$ or up to hatching time (9 dpf, T9), depending on the replicate under consideration. For the duration of the experiment, embryos and larvae were maintained at $26{ }^{\circ} \mathrm{C}$ with a $12 \mathrm{~h}: 12 \mathrm{~h}$ photoperiod and under static exposure conditions. After T9 sampling (corresponding to the hatching peak) the remaining embryos and larvae were kept in a clean medium, up to the $11^{\text {th }} \mathrm{dpf}$ to assess the genotoxic impact of the exposure on 2 days post-hatching larvae (dph). qRT-PCR and DNA damage measurement using the Comet assay. 
1 To complete this genetic aspect of the study, and as described in previous works from our laboratory

2 (Barjhoux et al. 2012; Vicquelin et al. 2011), a wide range of non-invasive phenotypic endpoints were

3 also studied. They included acute toxicity markers as embryonic survival and hatching success, and

4 markers of sublethal effects such as cardiac activity, biometric measurements, time to hatch and the

5 occurrence and spectrum of developmental abnormalities.

6 Finally, the time-course of Pyr and MePyr contamination was followed in the aqueous phase (i.e. in egg 7 rearing solution, ERS) at T0 (beginning of exposure) and at each sampling time dedicated to molecular 8 analysis (T7 and T9).

\subsection{Reference sediment characterization}

11 The reference sediment was collected in March 2010 in a pristine gravel pit near Yville-sur-Seine (Seine-

12 Maritime, France). This site has been shown to be marginally contaminated by heavy metals and organic pollutants (Cachot et al. 2006). Moreover, previous studies demonstrated that Yville-sur-Seine sediment

14 is an adequate substrate for medaka embryonic development without any toxic impact on medaka ELS

15 (Vicquelin et al. 2011; Cachot et al. 2007).

16 The reference sediment was stored at $-20^{\circ} \mathrm{C}$, then freeze-dried and lightly crushed using a mortar and a 17 pestle to eliminate larger particles and homogenize the grain size before use.

18 The physico-chemical characteristics of the sediment were analyzed using the processes described by 19 Barjhoux et al. (2012) and Vicquelin et al. (2011). As shown in Table 2, Yville-sur-Seine sediment can be 20 classified as fine sand with a low carbon organic content. Chemical analyses of this sediment showed a 21 very marginal presence of trace metallic elements and persistent organic pollutants.

\subsection{Sediment spiking procedure}

24 The freeze-dried $\left(-20\right.$ to $-40^{\circ} \mathrm{C}$, at 0.1 mbar for about 24 hours) reference sediment was spiked with Pyr or MePyr to obtain two different nominal concentrations of 300 (C1) and 3,000 ng/g dw (C2) for each compound. 
1 The consensus-based probable effect concentration (PEC) established for Pyr by MacDonald et al. (2000;

2 Table 1) was doubled to obtain the $\mathrm{C} 2$ nominal concentration. This PEC value was derived from the 3 analysis of sediment quality guidelines published previously and is defined as a threshold concentration

4 above which harmful effects on aquatic organisms are expected to occur frequently (MacDonald et al. 5 2000). The $\mathrm{C} 2$ concentration can thus be considered as 'toxicological', however such levels of Pyr

6 contamination can be achieved or exceeded in sediments from some particularly highly contaminated 7 sites (e.g. Boston harbor sediments; Table 1). The $\mathrm{C} 1$ concentration was set ten times lower than $\mathrm{C} 2$ 8 concentration. This treatment corresponded to Pyr concentrations that can be measured in contaminated 9 sediments from areas moderately affected by anthropogenic activities (e.g. old waste sites, harbor areas; 10 Table 1). The $\mathrm{C} 1$ concentration is also close to the mean threshold effect concentrations (TECs) reported 11 in Table 1 (including ERL, TEL and consensus-based TEC), below which adverse effects are not expected to occur. In order to compare the toxicity of Pyr and MePyr the same nominal concentrations were used for both compounds.

14 The spiking procedure was adapted from the protocol described by Vicquelin et al. (2011). Briefly, an 15 adequate amount of freeze-dried and crushed sediment from Yville-sur-Seine was placed in a $250 \mathrm{ml}$ 16 round-bottomed glass flask and immerged in dichloromethane (DCM, $2 \mathrm{ml} / \mathrm{g} \mathrm{dw}$ of sediment). Then, $2 \mathrm{ml}$ 17 of isooctane solution containing the required amount of the tested compound (Pyr or MePyr, purchased 18 from Sigma-Aldrich, Lyon, FR) was added to reach the target final concentration. Solvent evaporation was performed using a rotavapor (RV10 Basic, VWR International, Strasbourg, FR) equipped with a 20 heating water bath (HB10 Basic, VWR International) set at $45^{\circ} \mathrm{C}$ until the sediment was seen to be 21 completely dry. Any potentially remaining traces of organic solvent were eliminated by leaving the 22 sediment overnight at room temperature, in darkness, under an extractor hood. Finally, spiked sediment 23 from each treatment was divided into six aliquots of $12 \mathrm{~g} \mathrm{dw}$ (for embryo exposure) and one additional 24 aliquot of $5 \mathrm{~g} \mathrm{dw}$ dedicated to chemical analysis of Pyr and MePyr.

\subsection{Medaka embryo exposure}


1 Each aliquot of $12 \mathrm{~g} \mathrm{dw}$ of spiked sediment was laid in a $55 \mathrm{~mm}$-diameter plastic Petri dish and immerged

2 by adding $7 \mathrm{ml}$ of ERS (17.11 mM NaCl; $\left.0.4 \mathrm{mM} \mathrm{KCl} ; 0.36 \mathrm{mM} \mathrm{CaCl}_{2} ; 1.36 \mathrm{mM} \mathrm{MgSO}_{4} ; \mathrm{pH} 7.0\right)$. The

3 resulting system was then maintained at $26^{\circ} \mathrm{C}$ for a $4-5 \mathrm{~h}$ equilibration period before the beginning of the

4 experiment. Upon receipt of 24 hours post-fertilization (hpf) medaka eggs, healthiness and developmental

5 stage synchronism of the embryos were checked using a stereomicroscope (Leica MZ75, Leica

6 Microsystems, Nanterre, FR) and cold light source (Intralux ${ }^{\circledR}$ 4100, Volpi AG, Schlieren, CH).

7 Immediately after sorting, 70 embryos per replicate (six replicates per treatment) were randomly placed

8 on a Nytex ${ }^{\circledR}$ mesh (mesh opening $1000 \mu \mathrm{m}$, Sefar Filtration Inc., Depew, NY, US). The Nytex ${ }^{\circledR}$ grid was

9 then slightly sunk into the sediment. Afterwards, embryos remained exposed to the sediment in a climate

10 cabinet (Economic Delux, Snijders Scientific, Tilburg, NL) at $26 \pm 0.3{ }^{\circ} \mathrm{C}$ with a $12 \mathrm{h:} 12 \mathrm{~h}$ photoperiod

11 (5000 lx white light) until hatching time ( $9 \mathrm{dpf})$ and then placed in clean ERS medium up to the end of experiment at $11 \mathrm{dpf}$ (comet assay performed on 2-day old larvae). The remaining embryos or larvae were

13 euthanized using MS222 (Sigma-Aldrich) solution at $1 \mathrm{~g} / \mathrm{L}$. During the exposure period, the level of ERS

14 was checked daily and re-adjusted in case of evaporation. Dissolved oxygen was also checked daily at the 15 water-sediment interface using an oxygen optical microsensor (NeoFox ${ }^{\circledR}$ Foxy probe, Ocean Optics 16 sensors, Idle Fibres optiques, Lannion, FR). This measurement confirmed good oxygenation of the 17 medium with values always higher than $80 \%$ saturation (data not shown).

\subsection{Phenotypical endpoints}

20 The different procedures performed for phenotypic endpoint assessments have been previously detailed 21 by Barjhoux et al. (2012). Viability was checked daily for all individuals and all conditions. Cardiac activity was monitored in 6 and 7 dpf-embryos (5 randomly selected individuals per replicate). Biometric measurements (total body length, head size and head/body length ratio) and developmental anomalies (spinal, craniofacial, ocular, cardiovascular, yolk-sac and edema) were observed in 15 randomly selected newly hatched larvae per replicate. All these observations were done in an air-conditioned room at 23

$26 \pm 1{ }^{\circ} \mathrm{C}$ using a stereomicroscope (MZ75, Leica Microsystem) equipped with a color CCD camera (Leica 
1 DFC 420C), connected to an image analysis software program (Leica Application Suite v2.8.1.) and a 2 cold light source (Intralux ${ }^{\circledR} 4100$, Volpi AG).

\subsection{Gene transcription analysis}

5 Gene expression analysis was conducted on three samples of 8 pooled individuals per replicate, and on three replicates per treatment at each sampling time (T7 and T9).

A panel of 12 genes was selected for transcriptional analysis due to their involvement in xenobiotic metabolism, antioxidant defenses, mitochondrial metabolism, DNA repair, cell cycle regulation and apoptosis. The response to oxidative stress was studied through cytoplasmic $(\operatorname{sod}(\mathrm{Cu} / \mathrm{Zn}))$ and mitochondrial superoxide dismutase $(\operatorname{sod}(M n))$ gene transcription. Activation of Pyr and MePyr phase I metabolism was studied through cyplA gene transcription. The impact of Pyr and MePyr on the mitochondrial electron transport chain was investigated using cytochrome $\mathrm{C}$ oxidase subunit I (coxI) transcripts. The oggl (8-oxoguanine glycosylase 1) was selected for its involvement in oxidative DNA damage repair. PAH-induced apoptosis was studied through Bcl-2 associated X protein (bax) and p53 gene transcription levels. The wingless integration site 1 (wntl) gene was also selected for its key role in cell differentiation and proliferation. Finally, four genes involved in retinoid metabolism (retinaldehyde dehydrogenase type 2, raldh2) and retinoic acid signaling pathway (retinoic acid receptor alpha 1, raral; retinoic acid receptor gamma $1, \operatorname{rar} \gamma 1$; retinoid $\mathrm{X}$ receptor, $r x r \alpha 1$ ) were also studied. Each pool of embryos or larvae was entirely immerged in RNAse-free microtubes containing $200 \mu \mathrm{L}$ RNA Later ${ }^{\circledR}$ (Qiagen, Manchester, UK) and quickly frozen by dipping in liquid nitrogen. Samples were then stored at $-80{ }^{\circ} \mathrm{C}$ until RNA extraction. Total RNA extraction was performed using the Absolutely RNA ${ }^{\circledR}$ Miniprep kits (Agilent, Les Ulis, FR) according to the manufacturer's instructions, with an additional phenol-chloroform-isoamylic alcohol $(25: 24: 1, v / v)$ purification step. The quality and the quantity of the extracted RNA were determined by spectrophotometry at 260 and $280 \mathrm{~nm}$.

26 First-strand cDNA was synthesized using the AffinityScript ${ }^{\mathrm{TM}}$ Multiple temperature cDNA Synthesis kits 27 (Agilent). Briefly, $1 \mu \mathrm{L}$ of oligo dT $(1 \mu \mathrm{M}), 1 \mu \mathrm{L}$ of random primers $(1 \mu \mathrm{M}), 0.8 \mu \mathrm{L}$ of dNTPs $(10 \mathrm{mM})$ 
1 and $2 \mu \mathrm{L}$ of AffinityScript ${ }^{\mathrm{TM}} \mathrm{RT}$ buffer (10X) were mixed together with $14 \mu \mathrm{L}$ of the previously

2 extracted RNA (approximately $5 \mu \mathrm{g}$ ). The mixture was then incubated in a thermocycler (MasterCycler 3 pro $^{\mathrm{TM}}$, Eppendorf, Le Pecq, FR) for $5 \mathrm{~min}$ at $65^{\circ} \mathrm{C}$. cDNA synthesis was performed by adding $1 \mu \mathrm{L}$ of 4 reverse transcriptase $(1 \mathrm{U})$ and $0.5 \mu \mathrm{L}$ of RNase block ribonuclease inhibitor $(0.5 \mathrm{U})$ and then by 5 incubating the mixture at $42{ }^{\circ} \mathrm{C}$ for $1 \mathrm{~h}$. cDNA samples were then stored at $-20^{\circ} \mathrm{C}$ until quantitative real6 time PCR was performed.

7 The coding sequences of the 13 selected genes (Table 3) were obtained from the GenBank (PubMed $8 \mathrm{NCBI}$ ) and HGNC (Ensembl, EMBL - EBI) databases. The accession number of each coding sequence is 9 reported in Table 3. For each gene, specific primer pairs were determined using the LightCycler probe design software (v1.0, Roche, Meylan, FR) and are mentioned in Table 3. Primers were purchased from 11 Sigma-Aldrich (Easy Oligo ${ }^{\mathrm{TM}}$ ). The amplification of cDNA was monitored using the DNA intercaling dye SyberGreen I. Real-time PCR reactions were performed using an $\mathrm{Mx} 3000 \mathrm{P}^{\mathrm{TM}}$ system (Stratagene, Agilent) and Brilliant III Ultra-Fast

$14 \mathrm{SYBR}^{\circledR}$ Green QPCR Master Mix kits (Agilent) according to the manufacturer’s instructions. PCR reactions were prepared in 96 well-microplates adding $10 \mu \mathrm{L}$ of SYBR ${ }^{\circledR}$ Green QPCR master mix (2X), $7 \mu \mathrm{L}$ of ultra-pure water (nuclease-free PCR-grade water), $2 \mu \mathrm{L}$ of primer-pair mix $(2 \mu \mathrm{M})$ and $1 \mu \mathrm{L}$ of cDNA. Afterwards, PCR reactions consisted of an activation cycle $\left(10 \mathrm{~min}\right.$ at $\left.95^{\circ} \mathrm{C}\right)$ followed by 50 amplification cycles $\left(30 \mathrm{~s}\right.$ at $95^{\circ} \mathrm{C}, 40 \mathrm{~s}$ at $60{ }^{\circ} \mathrm{C}$ and $30 \mathrm{~s}$ at $\left.72{ }^{\circ} \mathrm{C}\right)$. The specificity of each amplification cycle was determined from the dissociation curve of the PCR product. These dissociation curves were obtained by following the SyberGreen fluorescence level during 21 a gradual heating of the PCR products from 65 to $95{ }^{\circ} \mathrm{C}\left(0.1{ }^{\circ} \mathrm{C} / \mathrm{s}\right)$. Relative quantification of each gene transcription level was normalized according to $\beta$-actin and $r p l 7$ genes using the $2^{-\Delta C t}$ method described by Livak and Schmittgen (2001), where $\Delta C t$ represents the difference between the cycle threshold (Ct) of a specific gene and the mean $\mathrm{Ct}$ of the housekeeping genes ( $\beta$-actin and $r p l 7$ genes in the present study).

\subsection{Comet assay}


1 DNA damage induced by Pyr and MePyr exposure was evaluated on a pool of five 2 dph-larvae (one pool

2 sampled per replicate on three replicates per treatment) using the comet assay. Cell dissociation and

3 comet assay procedures were carried out following the protocol of Morin et al. (2011). Briefly, pools of

4 larvae were digested in a MEM-Collagenase IV $0.125 \%(\mathrm{w} / \mathrm{v})$ medium, and cell viability was checked using a trypan blue exclusion test (only cell suspensions with viability superior to $80 \%$ were used). Once

6 embedded in a $1 \%$ low melting point agarose gel, cells were lysed (2.5 M NaCl, $0.1 \mathrm{M}$ EDTA,

$7 \quad 0.01 \mathrm{M}$ Tris; $\mathrm{pH}=10$; at $4{ }^{\circ} \mathrm{C}$ for $\left.1 \mathrm{~h}\right)$ and immerged in an electrophoresis buffer $(0.3 \mathrm{M} \mathrm{NaOH}, 1 \mathrm{mM}$

8 EDTA; $\mathrm{pH}>13$ ) for $15 \mathrm{~min}$ to allow the DNA to unwind. Then, electrophoresis was carried out at $25 \mathrm{~V}$,

$9300 \mathrm{~mA}$ for $15 \mathrm{~min}$. Ethidium bromide $(20 \mathrm{mg} / \mathrm{L})$ was used as DNA fluorescent tag and all coded-slides 10 were randomly analyzed for 75 nuclei per gel (two gels per experimental replicate) using an Olympus epi11 fluorescent microscope (400 x magnification) equipped with a grayscale CCD camera (Zeiss, DE) and the Komet 5.5 software program (Kinetic Imaging, Liverpool, UK). As recommended by Hartmann et al.

13 (2003), \% tail DNA (percentage of DNA which migrates from the nucleus i.e. the head of the comet) was 14 the selected parameter used for the measurement of DNA damage. Heavily DNA-damaged nuclei displaying a small or inexistent head and a large diffuse tail, known as 'hedgehog cells', were not taken into account in the comet measurement, according to the recommendations of Kumaravel et al. (2009). However, the percentage of hedgehog cells, which have also been reported as apoptotic or necrotic cells (Olive and Banath 1995), was visually scored on a total of 100 cells per gel.

\subsection{Pyr and MePyr analysis}

\subsubsection{Sediment analysis}

Pyr and MePyr extraction and analysis were performed according to the procedures described in previous studies (Devier et al. 2005; Letellier et al. 1999). In brief, spiked sediments were extracted using microwave-assisted extraction ( $30 \mathrm{~W}$ for $10 \mathrm{~min}$, in a Maxidigest 350, ProLabo, Fontenay-sous-Bois, FR) with $30 \mathrm{~mL}$ of DCM and $30 \mu \mathrm{L}$ of $\beta$-mercaptoethanol. Depending on the expected PAH concentration, the extracted quantity of freeze-dried sediment varied from $0.5 \mathrm{~g}$ (for $\mathrm{C} 2$ treatments) and $1 \mathrm{~g} \mathrm{dw}$ (control sediment and $\mathrm{C} 1$ spiking level). One extraction blank (complete procedure without matrix) was included 
1 in each series of extraction. Deuterated fluoranthene (Fluod10) was used as an internal standard and

2 gravimetrically added prior to the extraction procedure in each sample and blank.

3 After extraction, the samples were reconcentrated using a Vacuum Evaporation System (RapidVap,

4 Labconco, Fort Scott, KS, US; $900 \mathrm{mBars,} 50^{\circ} \mathrm{C}$ ). The concentrated extracts were then purified on a

5 micro-column containing activated copper and alumina and reconcentrated in isooctane. Afterwards,

6 purified samples were loaded onto a micro-column containing silica. The aliphatic fraction was discarded

7 by elution with pentane whereas the aromatic fraction containing the PAHs was subsequently eluted with

8 a mixture of DCM-pentane $(65: 35 \mathrm{v} / \mathrm{v})$. The aromatic extracts were reconcentrated in DCM and analyzed

9 using gas chromatography-mass spectrometry (GC-MS). Deuterated pyrene (Pyr10) was used as syringe

10 standard and gravimetrically added to each extract and blank just before injection.

11 The accuracy and the validity of the quantification method were tested during each analysis series using two standards solutions containing known amounts of Pyr, MePyr and deuterated standards (Fluod10 and 13 Pyr10). The first standard solution was used to evaluate the response factors (Pyr/Fluod10, 14 MePyr/Fluod10 and Fluod10/Pyr10). The second independent standard solution was used to test the 15 efficiency of the quantification method, which varied between $103 \%$ and $105 \%$ for Pyr, between $100 \%$ 16 and $101 \%$ for MePyr and between $98 \%$ and $99 \%$ for Fluod 10.

At each sampling time, approximately $4 \mathrm{~mL}$ of ERS was sampled from three replicates and pooled together for the same treatment (except for T0 sampling for which $20 \mathrm{ml}$ of clean ERS was analyzed). Aqueous samples were separated from sediment particles with a 15 min-centrifugation at $3500 \mathrm{~g}$ at $15{ }^{\circ} \mathrm{C}$ and stored at $-20^{\circ} \mathrm{C}$ in the dark until analysis. Pyr and MePyr extraction was performed by SPME (Solid Phase MicroExtraction) and analyzed by GC/MS as described by de Perre et al. (submitted). The same internal and syringe standards as mentioned for sediment analysis were used. The efficiency of the quantification method has been evaluated to be $116 \%$ for Pyr and $126 \%$ for MePyr. 
2 The data is expressed as mean \pm standard deviation (SD). Statistical analyses were conducted using

3 Statistica 7.1 software (Statsoft, Maisons-Alfort, FR). Results were initially tested for normality (Shapiro-

4 Wilk's test on residues with $1 \%$ risk) and homoscedasticity (Levene's test, 5\% risk). When necessary,

5 data was transformed to fulfill normality and homoscedasticity criteria. Afterwards, significant

6 differences between treatments were tested with a one-way or two-way ANOVA analysis followed by

7 post-hoc Tukey's test $(p<0.05)$. If data transformation was not sufficient to perform parametric analysis,

8 then the non-parametric Kruskall-Wallis' test followed by Bonferroni-Dunn's post-hoc test were used

$9(p<0.05)$. Finally, relative gene transcription data was statistically analyzed using the $t$ test for 10 independent samples (only pairing comparisons with the control treatment were performed).

\section{Results and discussion}

In previous studies, the MELAc proved to be a reliable, sensitive and integrative bioassay specifically designed for toxicity assessment of sediment bound chemicals including metals and hydrophobic substances (Barjhoux et al. 2012; Vicquelin et al. 2011). The present work proposes an adaptation of this assay for a combined analysis of embryotoxicity, teratogenicity and genetic disturbances induced by Pyr and MePyr in medaka ELS. During the time-course of the exposure to spiked sediments, several phenotypical and non-invasive markers of toxicity and embryonic development impairment were investigated in embryos and larvae. This approach was completed by the analysis of target gene transcription levels by qRT-PCR and DNA damage measurement using the comet assay.

\subsection{Pyr and MePyr contamination in the spiked-sediments and the water column}

Chemical analysis revealed a clear concentration-dependent increase of Pyr and MePyr content in Pyrand MePyr-spiked sediments, respectively (Table 4). The spiking efficiencies, calculated by comparison between Pyr or MePyr contents in sediment at $\mathrm{T} 0$ and the expected concentration based on the amount of compound introduced during the spiking procedure, were satisfying and varied between $83 \%$ and $92 \%$ for 
1 Pyr, and between $70 \%$ and $88 \%$ for MePyr. The resulting exposure concentrations in sediments were

2 close to the targeted values.

3 Pyr and MePyr concentrations in the aqueous phase of the control treatment were low and varied from

$4 \quad 1.48 \mathrm{ng} / \mathrm{L}$ to $12.5 \mathrm{ng} / \mathrm{L}$ for Pyr and from $0.16 \mathrm{ng} / \mathrm{L}$ to $3.5 \mathrm{ng} / \mathrm{L}$ for MePyr (Table 4). Pyr concentration in

5 the ERS buffer from the different treatments showed a trend of increasing over the time-course of the

6 experiment to reach maximal values of $630 \mathrm{ng} / 1$ and $3,125 \mathrm{ng} / \mathrm{L}$ at $\mathrm{T} 9$ in $\mathrm{C} 1$ and $\mathrm{C} 2$ treatments, 7 respectively. The same tendency was observed for the MePyr-C2 treatment for which MePyr 8 concentration peaked at $1,830 \mathrm{ng} / \mathrm{L}$ at the end of exposure. Surprisingly, the aqueous phase from the 9 MePyr-C1 treatment was more contaminated by MePyr at T7 $(98 \mathrm{ng} / \mathrm{L})$ than at T9 $(53.5 \mathrm{ng} / \mathrm{L})($ Table 4$)$. 10 The contamination of the water column is probably due to the desorption of Pyr or MePyr labile fraction 11 from the sediment particles and the diffusion of these compounds from the sediment pore-water. According to some authors, PAHs bioavailability (and thus, toxicity) is highly governed by their concentration in the aqueous phase and more particularly in the pore-water of contaminated soils or 14 sediments (Geffard et al. 2003; Sverdrup et al. 2002). In the present work, measured concentrations of Pyr and MePyr in the ERS buffer were relatively low and only reached a few $\mu \mathrm{g} / \mathrm{L}$ in the most highly contaminated treatments. However, it can be hypothesized that dissolved PAHs may have been locally more concentrated in sediment pore-water during the exposure. Sverdrup et al. (2002) proposed a method for the calculation of PAH concentration in pore-water as a function of PAH content in spiked sediments and their soil organic carbon-water partitioning coefficient $\left(\mathrm{K}_{\mathrm{oc}}\right)$. When applied to Pyr and MePyr sediment contents measured in the present work, concentrations in pore-water could reach 2.7 and

$2130 \mu \mathrm{g} / \mathrm{L}$ for $\mathrm{Pyr}$, and 1.16 and $14.9 \mu \mathrm{g} / \mathrm{L}$ for $\mathrm{MePyr}$, for $\mathrm{C} 1$ and $\mathrm{C} 2$ treatments, respectively (calculations carried out using an $n$-octanol-water partitioning coefficient, $\log \mathrm{K}_{\mathrm{ow}}$, equals to 5.2 for Pyr according to Sverdrup et al. (2002) and to 5.48 for MePyr as predicted by US-EPA EPI suite ${ }^{\mathrm{TM}}$ ). Concentrations measured in the aqueous phase at the end of the exposure were well below these predicted values.

\subsection{Only Pyr induces low mortality in embryos exposed to spiked-sediments.}


1 MePyr exposure did not induce any significant impact on survival rate in exposed embryos; the mean

2 viability was above $95 \%$ in both treatments (Table 5). Conversely, Pyr exposure resulted in a slight 3 concentration-dependent reduction of embryos survival, which was significant for the Pyr-C2 4 concentration when compared to the control $(p<0.03)$. However, mean embryonic survival in this treatment remained high $(>90 \%)$ and only represented a decline of $5 \%$ in comparison to unexposed 6 embryos (Table 5).

7 According to these observations and considering that only dissolved PAHs are biologically available for 8 fish embryos (Carls et al. 2008), a lethality threshold of $3 \mu \mathrm{g} / \mathrm{L}$ of Pyr in the water column can be 9 established for medaka embryos exposed to spiked-sediment. These results are in agreement with the 10 LOEC (lowest observed effect concentration) value of $2.5 \mu \mathrm{g} / \mathrm{L}$ reported for the survival of turbot larvae 11 (Psetta maxima) exposed to Pyr during 96 h (Mhadhbi et al. 2010). Li et al. (2011) also observed a 5\% to $1210 \%$ mortality in Sebastiscus marmoratus larvae exposed to $1 \mu \mathrm{g} / \mathrm{L}$ of Pyr. On the contrary, Cyprinodon 13 variegatus exposure to $20 \mu \mathrm{g} / \mathrm{L}$ of Pyr did not induce significant reduction of the embryonic survival rate 14 (Hendon et al. 2008). It has also been reported that Pyr-induced lethality following embryonic exposure mainly occurred at the larval stage, several days after hatching (Hendon et al. 2008; Incardona et al. 2004). It is thus possible that additional mortality could occur in medaka ELS if the exposure was prolonged later at the larval stage. Based on the above mentioned data, it seems that medaka ELS have similar sensitivity to $P$. maxima larvae but are clearly more sensitive than $C$. variegatus embryos when exposed to Pyr in the water column. Nonetheless, it must be emphasized that, as discussed above (see part 3.1), Pyr could be more concentrated in sediment pore-water (up to $30 \mu \mathrm{g} / \mathrm{L}$, according to Sverdrup et al.'s (2002) calculation method), thus leading to higher exposure concentrations when fish embryos develop at the surface or in the sediment. Additionally, other studies suggested that particle-bound PAHs could also contribute to the toxic effects acting as a secondary source of contamination in embryos exposed to contaminated sediments (Hollert et al. 2003; Kocan et al. 1996). Consequently, it seems relevant to specify Pyr concentrations in sediment when establishing toxicity threshold values using a sediment-contact bioassay. The present study thus revealed the relatively low acute toxicity of Pyr in 
1 medaka embryos with a lethality threshold equal to $2.8 \mu \mathrm{g} / \mathrm{g} \mathrm{dw}$ in the sediment and $3 \mu \mathrm{g} / \mathrm{L}$ of Pyr in the

2 water column.

\subsection{Pyr and MePyr impact in ovo development of medaka embryos}

Hatching success and time to hatch of embryos was recorded over a $11 \mathrm{dpf}$-period (Table 5). However not significant, a concentration-dependent decrease of hatching success was observed following Pyr exposure, down to $71 \%$ for the $\mathrm{C} 2$ treatment. The mean time to hatch in Pyr exposed treatments was consistently delayed in a concentration-dependent way although not significantly different from the control treatment ( $p>0.05$ according to ANOVA results followed by Tukey's post-hoc test; Table 5). Only $46 \%$ of the embryos exposed to MePyr-C1 concentration hatched during the 11 dpf-period which resulted in a mean time to hatch of $10.8 \mathrm{dpf}$ for this treatment (Table 5). This significant $(p<0.05)$ impairment of the hatching success and the time to hatch in comparison to the control indicates that medaka embryonic development was noticeably delayed/halted by MePyr at concentrations of $202 \mathrm{ng} / \mathrm{g}$ $\mathrm{dw}$ in sediment and up to $98 \mu \mathrm{g} / \mathrm{L}$ in the water column. Surprisingly, exposure to the highest concentration of MePyr did not noticeably impact hatching success, It could be interpreted as a hormesitic effect of MePyr exposure on hatching events, however, further experiments are needed using a wider concentration range to conclude.

Medaka in ovo growth was evaluated through biometric measurements acquisition on newly hatched larvae. Results showed a concentration-dependent reduction of larvae total body length following exposure to both Pyr and MePyr (Fig. 1). On average, larvae exposed to C2 treatments were significantly

$214 \%$ - and 5\%-shorter than control larvae in Pyr and MePyr treatments, respectively $(p<0.02$ for Pyr and $p<0.01$ for MePyr). Nevertheless, no significant effect of Pyr and MePyr was highlighted on the average head size of newly hatched larvae (Fig. 1) or on head/body length ratio (Data not shown). As a result, analysis of general in ovo development endpoints (including hatching success; time to hatch and larval length) demonstrated that Pyr significantly altered medaka growth at the highest concentration $(2.8 \mu \mathrm{g} . \mathrm{g}$ $\mathrm{dw}$ of sediment and up to $3.1 \mu \mathrm{g} / \mathrm{L}$ in the aqueous phase) and that MePyr impacted on embryonic 
1 development from the lowest concentration $(0.2 \mu \mathrm{g}$.g dw of sediment and up to $0.1 \mu \mathrm{g} / \mathrm{L}$ in the aqueous 2 phase).

3 A concentration-dependent inhibition of hatching success was reported in P. maxima embryos exposed to 4 Pyr from 1.25 to $40 \mu \mathrm{g} / \mathrm{L}$ (Mhadhbi et al. 2010). Hatching rate (but not time to hatch) was also 5 significantly reduced in C. variegatus embryos exposed to $150 \mu \mathrm{g} / \mathrm{L}$ of Pyr and $18 \mathrm{dpf}$-larvae showed a 6 reduced body length following exposure to $20 \mu \mathrm{g} / \mathrm{L}$ (Hendon et al. 2008). Likewise, Rhodes et al. (2005) 7 reported a strong reduction of hatching success and larval hatching length in medaka ELS exposed to an 8 environmental extract characterized by a high content of alkyl-PAH. The authors assumed that PAH 9 metabolites could impair energy metabolism resulting in an inhibition of hatching success since escaping 10 the chorion is highly energy dependent. It could also be suggested that PAH biotransformation is energy11 consuming, therefore limiting the energy store available for growth and hatching. These hypotheses are thus coherent with reduced growth (i.e. larval length) of newly hatched medaka larvae following exposure to environmental PAH extracts (Farwell et al. 2006; Rhodes et al. 2005) and to Pyr and MePyr in the 14 present work. However, other observations seem to indicate that the reduction of larva body size following PAH exposure is linked to the decreased absorption of yolk due to cardiovascular dysfunction (Billiard et al. 1999; see part 3.5 for details).

\subsection{Pyr and MePyr are highly teratogenic in medaka ELS}

19 Observations of developmental abnormalities in newly hatched medaka larvae following embryonic exposure to spiked-sediments revealed the high teratogenic potency of both Pyr and MePyr. Indeed, a

21 significant ( $p<0.001$, when compared to the control) and dramatic increase of the percentage of abnormal larvae, above $80 \%$ in all treatments, was observed from the lowest concentrations of Pyr and MePyr, (Fig. 2). Such high percentages of affected larvae have been reported in medaka ELS exposed to phenanthrene and alkyl-phenanthrenes up to $1000 \mu \mathrm{g} / \mathrm{L}$ (Turcotte et al. 2011) and in C. variegatus larvae following exposure to $150 \mu \mathrm{g} / \mathrm{L}$ of $\mathrm{Pyr}$ (Hendon et al. 2008).

In the present study, exposed larvae were significantly affected by cardiovascular impairments (at all tested concentrations of Pyr and MePyr), spinal deformities (in the MePyr-C2 treatment), yolk sac 
1 resorption defects (in both Pyr treatments and at the highest concentration of MePyr) and cranio-facial

2 abnormalities (in the Pyr-C2 treatment) in comparison to the control group (Fig. 2). Most of these

3 developmental abnormalities have already been described in fish ELS following exposure to Pyr (Li et al.

4 2011; Mhadhbi et al. 2010; Incardona et al. 2004). Interestingly, many of these defects have also been observed in fish ELS exposed to TCDD (Antkiewicz et al. 2005; Hornung et al. 1999; Elonen et al. 1998)

6 and are often assimilated to blue sac disease (BSD) symptoms.

\subsection{Pyr and MePyr exposure strongly affects the cardiovascular system of embryos}

9 The cardiovascular system is known to be particularly sensitive to PAH exposure in fish ELS (Carls et al. 2008; Incardona et al. 2004). In the present study, Pyr and MePyr exposure did not significantly affect cardiac activity in 6 dpf- and 7 dpf-embryos (Data not shown). However, PAH exposure induced a significant concentration-dependent increase of the percentage of larvae showing cardiovascular injuries in all exposed treatments in comparison to the control (Fig. 2). This kind of developmental defect was the most frequently observed and affected $76 \%$ to $87 \%$ of the larvae exposed to Pyr and $61 \%$ to $81 \%$ of the larvae from MePyr treatments. These impairments included abnormal positioning of the heart chambers in relation to each other and to the cephalo-caudal axis as well as heart hypo-, hyper- or dystrophies.

Antkiewicz et al. (2005) also observed altered heart looping resulting in abnormal relative positioning of the heart chambers, hypo- and dystrophy of the heart chambers in zebrafish embryos exposed to TCDD. Heart morphology impairments were associated with cardiac dysfunction and/or vascular circulatory defects, even if both cause and effect relationship remained possible (Antkiewicz et al. 2005).

21 Similarities between Pyr and TCDD cardiotoxicity have been already reported in zebrafish ELS (Incardona et al. 2006; 2004). However, in this species, Pyr mainly induced anemia syndrome, reduced vascular peripheral circulation, pericardial and yolk sac edemas (Incardona et al. 2004). Interestingly, $D$. rerio embryos exposure to phenanthrene and benzo[a]anthracene caused the appearance of similar cardiovascular pathologies as described by Antkiewicz et al. (2005) and the present study. 
1 Although not significant, pericardial edemas were observed in larvae following exposure to both Pyr 2 treatments ( $9 \%$ to $13 \%$ ) and $\mathrm{MePyr}-\mathrm{C} 2$ concentration (8\%; Fig. 2) with a $p$ value close to significance 3 threshold for Pyr-C2 treatment $(p=0.06)$. Similar observations were reported in C. variegatus larvae

4 exposed to $150 \mu \mathrm{g} / \mathrm{L}$ of Pyr (Hendon et al. 2008). According to Billiard et al. (1999), the appearance of edemas in rainbow trout and zebrafish larvae exposed to retene suggested leakiness of the endothelial

6 vasculature and may be an overt sign of cardiovascular dysfunction. Considering that the vitelline vessels supplying yolk to the embryo are critical for absorption of yolk nutriments, loss of vascular integrity could interfere with release of yolk metabolites to vitelline circulation (Billiard et al. 1999). In the present study, reduced yolk absorption was significantly induced in a concentration-dependent way in newly hatched larvae exposed to both Pyr treatments and to MePyr-C2 treatment, in comparison to the control group ( $p<0.05$; Fig. 2). As described above, these effects were concomitant to a decrease of larval body length and cardiovascular injuries in larvae exposed to Pyr and MePyr C2-treatments. Moreover, cardiovascular dysfunction has been linked with decreased absorption of the yolk sac in medaka ELS exposed to TCDD (Elonen et al. 1998). All these observations suggest that Pyr and MePyr-induced inhibition of growth is the consequence of yolk malabsorption in exposed larvae, as a result of cardiovascular dysfunctioning, as previously suggested for TCDD (Antkiewicz et al. 2005; Elonen et al. 1998). The reduced vascular peripheral circulation observed in D. rerio early larval stage exposed to Pyr (Incardona et al. 2006, 2004) seems to corroborate this hypothesis.

\subsection{Skeletal deformities induction following embryonic exposure to Pyr and MePyr} Although cardiovascular injuries were the main developmental abnormalities induced by Pyr and MePyr exposure, skeletal deformities were also recorded in exposed larvae at hatching. Indeed, $26 \%$ to $29 \%$ of Pyr-exposed larvae and $40 \%$ to $47 \%$ of MePyr-exposed larvae $(p<0.05$ for MePyr-C2 treatment when compared to control, according to one-way ANOVA followed by Tukey's post-hoc test) showed abnormal spinal curvature including lordosis, kyphosis and C-shaped larvae (Fig. 2). Additionally, 19\% and $25 \%$ of the larvae exposed to $\mathrm{Pyr} \mathrm{C} 1-$ and $\mathrm{C} 2$ treatments respectively, showed craniofacial abnormalities primarily in the lower jaw (Fig. 2, $p=0.053$ and $p<0.05$ respectively). Similar 
1 developmental impairments were also noticeable in $23 \%$ of larvae from MePyr C1-treatment $(p=0.053$ in

2 comparison to control; Fig. 2).

3 Comparable spinal and jaw deformities have been reported in several fish larvae following exposure to

4 Pyr (Li et al. 2011; Hendon et al. 2008; Incardona et al. 2006). Such developmental defects were also induced in fish ELS exposed to TCDD (Teraoka et al. 2006, 2002; Elonen et al. 1998). The concomitant

6 induction of CYP1A (at the protein and mRNA levels) and occurrence of skeletal defects in C. variegatus 7 and D. rerio larvae suggested that CYP1A pathway is involved in the development of spinal deformities 8 in Pyr-exposed organisms (Hendon et al. 2008; Incardona et al. 2006). Moreover, spinal deformities 9 (mainly kyphosis or lordosis) were reported in Pacific herring (Clupea pallasi) larvae following exposure to weathered crude oil (Carls et al. 1999). The authors also noticed that deformed larvae showed difficulties to swim normally and that spinal curvature was the most important predictor of swimming ability. As reduced swimming ability may also impact upon prey capture capacity or predator escape performance, these observations suggested that additional mortality could occur in heavily affected individuals after complete resorption of yolk reserves.

Wnt-1 signaling pathway is highly implicated in embryogenesis and morphogenesis through cell differentiation and proliferation control (L'Allemain 2006). In particular, Wnt signaling (including Wnt-1 members) is involved in the dorso-ventral patterning of the spinal cord, promoting dorsal identities in combination to Sonic hedgehog (Shh) pathway which induces ventral ones (Ulloa and Marti 2010). Several lines of evidence indicate that antagonist interactions between these two signaling pathways, highly conserved through evolution, would define the dorso-ventral patterning of the developing central nervous system and direct myotome formation (Ulloa and Marti 2010; Münsterberg et al. 1995). In the present study, wntl transcription level was significantly increased in comparison to control in medaka larvae following exposure to Pyr-C1 treatment $(p<0.05)$ and both MePyr concentrations $(p<0.01$, Table 6). Supporting these observations, Fairbairn et al. (2012) reported that the exposure of D. rerio embryos to phenanthrene and fluorene induced morphological abnormalities resulting from the disruption of embryonic axis determination and a concomitant increase in the levels of nuclear $\beta$-catenin throughout the embryo (suggesting the aberrant activation of Wnt/ $\beta$-catenin pathway). Similar observations were made in 
1 sea urchin (Lytechinus anemesis) embryos exposed to creosote and PAHs (Pillai et al. 2003). According

2 to these studies, it seems that PAHs disrupt dorsal-ventral axis determination in the embryos via the 3 Wnt/ß-catenin signaling pathway (Fairbairn et al. 2012). It is thus possible that some of the spinal 4 deformities observed in the present study following exposure of medaka embryos to Pyr and MePyr could result from Wnt signaling disturbance during somitogenesis as suggested for Cd (Chow and Chen 2003).

6 Similarly, exposure of $S$. marmoratus embryos to benzo[a]pyrene resulted in spinal and cranio-facial 7 deformities (including lower jaw deformities) in association to the inhibition of $s h h$ transcription levels 8 (He et al. 2011). Likewise, D. rerio embryos exposure to TCDD caused lower jaw deformities and the $a h r 2$-dependent down-regulation of $s h$ genes transcription (Teraoka et al. 2006). The authors of these studies concluded that craniofacial deformities induced by benzo[a]pyrene and TCDD could be the result of Shh signaling pathway impairment, leading to a failure of cell proliferation (He et al. 2011; Teraoka et al. 2006). Considering the antagonist interactions existing between Wnt and Shh pathways, it is possible that some spinal and craniofacial deformities observed in the present study following medaka embryos exposure to Pyr and MePyr are the result of Wnt signaling pathway disruption, as suggested by the significant increase of wntl transcription level (Table 6). Moreover, recent genomic analysis performed in a zebrafish tissue regeneration model revealed functional cross talk between AhR and the Wnt/ $\beta$-catenin signal transduction pathway (Lijoy et al. 2009). It thus can be hypothesized that the AhR pathway is involved in Wnt signaling disruption as Shh pathway deregulation was shown to be AhR-dependent following TCDD exposure (Teraoka et al. 2006).

\subsection{Impact of Pyr and MePyr exposure on retinoid metabolism genes transcription}

The impact of Pyr and MePyr exposure on retinoid metabolism was investigated through the analysis of retinoic acid receptors ( $\operatorname{rar} \alpha 1$, rary 1 and $r x r \alpha 1)$ and raldh 2 transcription levels. In 7 dpf-embryos exposed to Pyr-C2 treatment, rxr 1 transcription level tended to increase in comparison to control treatment ( $p=$ 0.07, Table 6). Similarly, exposure to MePyr-C2 concentration significantly stimulated rara1 transcription in medaka embryos ( $p<0.05$, according to $t$ test when compared to control). These modulations of retinoic acid receptor transcripts were simultaneous to cypla transcription induction 
$1 \quad(p<0.05$, Table 6). The raral transcription levels were still overexpressed when compared to control in

2 larvae exposed to both MePyr treatments $(p<0.02)$ and $r x r \alpha 1$ transcripts level in larvae was close to

3 significant threshold $(\mathrm{p}=0.08)$ when compared to control in MePyr-C1 treatment. Moreover, raldh2 gene

4 transcripts were also significantly up-regulated in newly hatched larvae exposed to the highest

5 concentration of MePyr. If also reflected at the protein level, the modulations of these genes could

6 indicate an increased transformation of retinoid reserves or retinol into retinoic acid and the activation of

7 the RXR/RAR pathway. It is consistent with the reduction of retinoid stores correlated to CYP1A or

8 EROD induction observed in fish exposed to PAHs (Arcand-Hoy and Metcalfe 1999; Besselink et al.

9 1998). Furthermore, a concentration-dependent increase of all-trans-retinoic acids concentration as well

10 as CYP1A1 activity and cyplal mRNA level were observed in TCDD-exposed rats, suggesting that

11 CYP1A pathway is involved in retinoic acid synthesis induced by dioxin (Schmidt et al. 2003). All these observations suggest that, as for TCDD, the AhR/CYP1A pathway is involved in retinoid metabolism

13 deregulation induced by Pyr and MePyr. Molecular and physiological interactions between retinoid 14 signaling and AhR pathways have been investigated in medaka embryos (Hayashida et al. 2004). The study demonstrated that both retinoic acid and its receptors RXR/RAR were required for AhR mRNA expression. In particular, the study evidenced that (1) retinoic acid excess and activation of RXR/RAR receptors led to ahr transcription up-regulation; (2) retinoic acid excess and AhR activation resulted in vascular damage and body-axis malformations. Consequently, it is possible that retinoid metabolism and signaling pathway deregulation following Pyr and MePyr exposure is involved in the appearance of at least a part of skeletal and cardiovascular deformities in exposed fish ELS. However, other investigations are needed to demonstrate if retinoid system disruption plays a critical role in Pyr and MePyr teratogenicity.

\subsection{Pyr and MePyr exposure modulates transcription of genes involved in mitochondrial} metabolism

Gene transcription analysis performed on embryos exposed to Pyr-C2 and both MePyr treatments 
1 Table 6). CoxI gene product is a mitochondria encoded subunit of complex IV of the mitochondrial

2 respiratory chain. Significant increase of coxI transcripts level has been already reported in the kidney and 3 the liver of O. mykiss juveniles exposed to Pyr (Krasnov et al. 2005). The stimulation of its transcription 4 could be interpreted as a compensatory response of embryos to exposure to Pyr and MePyr. Indeed, as 5 COX is considered as the rate-limiting step for mitochondrial respiration, coxI transcripts overexpression 6 could indicate an attempt of the organism to restore a decrease in mitochondrial activity (i.e. ATP 7 synthesis) and to efficiently consume $\mathrm{O}_{2}$, thus limiting ROS overproduction (Achard-Joris et al. 2006).

8 Considering that biologically activated PAHs could disrupt oxidative phosphorylation which may 9 interrupt the mitochondrial electron transport chain, a reduction in available ATP and subsequent energy reserves have been proposed as a possible mechanism to explain the decreased hatching success in medaka ELS exposed to PAH and alkyl-PAH (Rhodes et al. 2005). A depletion of available energy stores during embryonic development could thus also be responsible for the decrease of larval growth (in Pyrand MePyr-C2 treatments) as well as the reduced and delayed hatching events (in MePyr-C1 treatment) observed in the present study. However, it remains unclear if the impact of these PAHs on the energy reserves is the result of an impairment of the mitochondrial electron transport chain functioning and/or of an important allocation of available energy to biotransformation of xenobiotics. This latter hypothesis seems to be supported by the concomitant overexpression of cypla and coxI genes transcripts in medaka embryos exposed to the highest concentration of Pyr and MePyr (Table 6).

\subsection{Induction of DNA damage by Pyr and MePyr}

21 The potential induction of DNA damage by Pyr and MePyr was evaluated in 2 dph-larvae using the comet assay. DNA strand breaks were not significantly induced in comparison to the control $(p>0.05)$, although a concentration-dependent increase trend of the percentage of tail DNA was observed (Fig. 3). Conversely, the percentage of hedgehog cells (i.e. those with heavily DNA damaged nuclei) significantly increased in larvae from Pyr-C1 and MePyr-C2 treatments when compared to the control $(p<0.01$, Fig. 3).

26 Moreover, $p 53$ transcripts were significantly overexpressed in larvae exposed to the two concentrations of 27 MePyr $(p<0.05$, Table 6). If reflected at the protein level, $p 53$ induction could result in cell cycle arrest 
1 before the $\mathrm{S}$ phase to allow repair of DNA damage prior to DNA replication o[ $\mathrm{r}$ the induction of apoptosis

2 in cases where DNA damage is too severe to be properly repaired (Basu and Haldar 1998). DNA damage

3 could be the result of ROS overproduction as suggested by coxI transcription induction (see part 3.8).

4 This hypothesis is supported by oggl gene expression whose encoded protein is involved in the base

5 excision repair mechanism in the case of oxidative lesions of DNA. Indeed oggl transcripts were

6 significantly up-regulated in larvae following exposure to MePyr-C1 treatments $(p<0.05)$ and close to the

7 significant threshold ( $p=0.05$ in comparison to the control; Table 6) in medaka larvae exposed to MePyr-

$8 \mathrm{C} 2$ concentrations. However, no significant induction of the antioxidant $\operatorname{sod}(\mathrm{Mn})$ and $\operatorname{sod}(\mathrm{Cu} / \mathrm{Zn})$ gene

9 transcripts was noticeable to confirm ROS overproduction following exposure to Pyr and MePyr ( $p>0.05$

10 in comparison to the control; Table 6).

11 In summary, the present study demonstrated (1) no significant induction of DNA strand breaks (illustrated

12 by the percentage of tail DNA) by either Pyr or MePyr; (2) a significant increase in the percentage of 13 hedgehog cells by Pyr and MePyr; and (3) p53 and ogg1 transcription levels induction following MePyr 14 exposure. Further investigations are needed to conclude on the impact of Pyr exposure on DNA integrity 15 in medaka ELS. However, we could hypothesize that MePyr exposure induces oxidative DNA damage 16 that is fully repaired by DNA repair enzymes (such as Ogg1), except in the case of heavily DNA damaged 17 cells (i.e. hedgehog cells) in which apoptosis could be initiated through the p53-pathway. This latter hypothesis is supported by the observation of cell death in the brain and the spinal cord of $D$. rerio embryos exposed to Pyr (Incardona et al. 2004). Apoptotic cell death was also reported in medaka embryonic vasculature following TCDD exposure (Cantrell et al. 1998).

Interestingly, p53 transcription overexpression following MePyr exposure was simultaneous to wnt 1 transcription level induction (Table 6). There is little evidence to suggest that an abnormal activation of the Wnt pathway (including the wnt 1 gene) could deregulate the normal ontogenesis process by affecting cell differentiation (L'Allemain 2006). Moreover, aberrant Wnt signaling has been reported to be involved in some development of cancers which most likely results from inappropriate gene activation mediated by stabilized $\beta$-catenin (Polakis 2000; L'Allemain 2006). Recently, an anti-differentiation 
1 embryonic stem cells (Lee et al. 2010). The authors concluded that p53 could become 'tumorigenic' if the

2 induction of Wnt ligands by p53 is inherited aberrantly by the progeny cells of embryonic stem cells.

3 Further specific studies on the implication of p53 and Wnt pathways in ontogenesis mechanisms of fish

4 embryos could bring new insight into the potential carcinogenicity of MePyr.

5

\subsection{Implication of CYPIA pathway in Pyr and MePyr toxicity}

The overall toxic effects of Pyr and MePyr in medaka ELS highlighted in the present study overlapped considerably with those induced following TCDD exposure. Such similarities between Pyr and TCDD toxicity have been already reported and suggest the involvement of the AhR/CYP1A metabolism pathway (e.g., Hendon et al. 2008; Incardona et al. 2006, 2005).

Supporting this hypothesis, cyplA transcription levels were significantly induced when compared to the control in embryos exposed to the highest concentration of Pyr and MePyr ( $p<0.05$, Table 6). Cypla induction factors were moderate with values equal to 1.8 and 2.5 for Pyr and MePyr respectively, which seems to be in agreement with their relative AhR-agonist potency in comparison with other strong AhRagonists such as TCDD or benzo[a]pyrene (Barron et al. 2004). Cypla transcript induction was still noticeable in larvae from the Pyr-C2 treatment with a $p$-value close to the significant threshold in comparison to the control $(p=0.076)$.

CYP1A induction was reported throughout the vascular endothelium and the liver of D. rerio larvae exposed to Pyr (Incardona et al. 2006). The induction of this enzyme preceded and accompanied the emergence of developmental defects (including dorsal curvature, anemia, edemas, cell death and reduced peripheral circulation) and systemic toxicity induced by Pyr exposure. Moreover, Pyr-induced mortality was time-coincident with alterations in the appearance of the liver (Incardona et al. 2006). Gene silencing with $a h r 2$ antisense morpholino largely prevented teratogenicity and lethal effects of Pyr in D. rerio embryos and also markedly reduced the levels of CYP1A induction (Incardona et al. 2005). Similarly, an ahrla morpholino injection partially improved embryos resistance to Pyr toxicity, including normal liver appearance and absence of pericardial edemas and neural tube cell death. Cypla knockdown also reduced defects in embryos exposed to Pyr (Incardona et al. 2005). Moreover, Pyr-induced lethality was prevented 
1 or markedly delayed by several hours in cypla, ahrl and ahr2 morphants (Incardona et al. 2006, 2005).

2 Evidence gathered in these studies indicates that: (1) the toxic effects of Pyr are clearly AhR/CYP1A-

3 dependent; (2) the metabolism of Pyr by CYP1A in the vascular endothelium probably contributes to the

4 emergence of some teratogenic effects, in particular dorsal curvature; (3) hepatic CYP1A activity strongly

5 contributes to the systemic toxicity of Pyr, probably through the formation of Pyr toxic metabolite(s)

6 (Incardona et al. 2006, 2005).

7 This last assumption is supported by the positive correlation between DNA damage and the level of

8 biliary hydroxylated metabolites (mainly 1-OH-Pyr) observed in juvenile flatfish (Solea solea) exposed to

9 a mixture of benzo[a]pyrene, fluoranthene and pyrene (Wessel et al. 2010). The authors concluded that

10 PAH-induced DNA strand breaks probably result from the induction of oxidative stress by pro-oxidant

11 PAH metabolites and the excision activity of DNA repair enzymes. Furthermore, it has been demonstrated that ROS formation could occur during the CYP1A catalytic cycle or in a latter step of PAH

13 biotransformation, during quinones redox cycle (Baulig et al. 2003; Morel et al. 1999). To conclude, it 14 seems that the AhR/CYP1A pathway is strongly involved in Pyr and MePyr toxic effects as it could 15 contribute, directly or indirectly, to ROS overproduction, genotoxicity, teratogenicity and finally systemic 16 toxicity of both compounds.

\section{Conclusion}

The effects of environmental concentrations of Pyr and MePyr were investigated in medaka ELS exposed by sediment-contact. Both compounds strongly impacted medaka embryonic development, with the cardiovascular system as primary target of toxicity. Developmental abnormalities also included spinal and jaw deformities observed in medaka larvae following Pyr and MePyr exposure considerably overlapped those induced by TCDD. In addition, the transcription level of several genes involved in mitochondrial metabolism, cell differentiation and proliferation control, cell cycle arrest and retinoid metabolism was significantly deregulated. Significant increase in cypla transcript levels suggested that AhR/CYP1A pathway is involved in several toxic effects induced by Pyr and MePyr exposure. Overall, the results 
1 showed that exposure to the tested environmental concentrations of Pyr and MePyr in sediment has a

2 clear impact on the development of medaka embryos resulting in noticeable effects at both phenotypical

3 and transcriptional levels. These observations highlight the ecotoxicological risk presented by these

4 compounds in PAH impacted areas. The present study also showed new aspects of the mode of action of

5 Pyr and, for the first time, the effects of MePyr were investigated in fish ELS. With regards to the

6 efficiency of the MELAc and the relevance of the route of exposure, this approach could be applied to the

7 investigation of the toxico-kinetics and toxico-dynamics of various chemicals including particle-bound 8 pollutants in fish ELS.

\section{Acknowledgments}

11 This study was supported by the Aquitaine region, the Seine-Aval program, the French national program EC2CO (GenerationPop research project) and the University of Bordeaux 1. Iris Barjhoux received a PhD fellowship from the Ministère de l'Enseignement Supérieur et de la Recherche (France).

\section{References}

Achard-Joris M, Gonzalez P, Marie V, Baudrimont M, Bourdineaud JP (2006) Cytochrome $c$ oxydase subunit I gene is up-regulated by cadmium in freshwater and marine bivalves. BioMetals 19:237-244

Antkiewicz DS, Burns CG, Carney SA, Peterson RE, Heideman W (2005) Heart malformation is an early response to TCDD in embryonic zebrafish. Toxicol Sci 84:368-377

Arcand-Hoy LD, Metcalfe CD (1999) Biomarkers of exposure of brown bullheads (Ameiurus nebulosus) to contaminants in the lower Great Lakes, North America. Environ Toxicol Chem 18:740-749

Barjhoux I, Baudrimont M, Morin B, Landi L, Gonzalez P, Cachot J (2012) Effects of copper and cadmium spiked-sediments on embryonic development of Japanese medaka (Oryzias latipes). Ecotoxicol Environ Saf 79:272-282

Barron MG, Heintz R, Rice SD (2004) Relative potency of PAHs and heterocycles as aryl hydrocarbon receptor agonists in fish. Mar Environ Res 58:95-100

Basu A and Haldar S (1998) The relationship between Bcl2, Bax and p53: consequences for cell cycle progression and cell death. Mol Human Reprod 4:1099-1109 
Baulig A, Garlatti M, Bonvallot V, Marchand A, Barouki R, Marano F, Baeza-Squiban A (2003) Involvement of reactive oxygen species in the metabolic pathways triggered by diesel exhaust particles in human airway epithelial cells. Am J Physiol Lung Cell Mol Physiol 285:L671-679

Besselink HT, Flipsen E, Eggens ML, Vethaak AD, Koeman JH, Brouwer A (1998) Alterations in plasma and hepatic retinoid levels in flounder (Platichthys flesus) after chronic exposure to contaminated harbour sludge in a mesocosm study. Aquat Toxicol 42:271-285

Billiard SM, Meyer JN, Wassenberg DM, Hodson PV, Di Giulio RT (2008) Nonadditive effects of PAHs on early vertebrate development: Mechanisms and implications for risk assessment. Toxicol Sci $105: 5-23$

Billiard SM, Querbach K, Hodson PV (1999) Toxicity of retene to early life stages of two freshwater fish species. Environ Toxicol Chem 18:2070-2077

Boily M, Bisson M, Spear PA (2004) Retinoids - Biomarkers and molecular basis for chemicals toxic effects (Rétinoïdes - Biomarqueurs et base moléculaire d'effets de substances toxiques). In: Pelletier E, Campbell PGC \& Denizeau F (eds) Ecotoxicologie Moléculaire - Principes fondamentaux et perspectives de développement. Presses de l'Université du Québec, Sainte-Foy, Québec, pp 197-256

Brinkworth LC, Hodson PV, Tabash S, Lee P (2003) CYP1A induction and blue sac disease in early developmental stages of rainbow trout (Oncorhynchus mykiss) exposed to retene. J Toxicol Environ Health A 66:627-646

Cachot J, Law M, Pottier D, Peluhet L, Norris M, Budzinski H, Winn R (2007) Characterization of toxic effects of sediment-associated organic pollutants using the lambda transgenic medaka. Environ Sci Technol 41:7830-7836

Cachot J, Geffard O, Augagneur S, Lacroix S, Le Menach K, Peluhet L, Couteau J, Denier X, Devier MH, Pottier D, Budzinski H (2006) Evidence of genotoxicity related to high PAH content of sediments in the upper part of the Seine estuary (Normandy, France). Aquat Toxicol 79:257-267

Cailleaud K, Forget-Leray J, Souissi S, Hilde D, LeMenach K, Budzinski H (2007) Seasonal variations of hydrophobic organic contaminant concentrations in the water-column of the Seine Estuary and their transfer to a planktonic species Eurytemora affinis (Calanoïda, copepoda), Part 1: PCBs and PAHs. Chemosphere 70:270-280

Cantrell SM, Joy-Schlezinger J, Stegeman JJ, Tillitt DE, Hannink M (1998) Correlation of 2,3,7,8tetrachlorodibenzo- $p$-dioxin-induced apoptotic cell death in the embryonic vasculature with embryotoxicity. Toxicol Appl Pharm 148:24-34

Carls MG, Holland L, Larsen M, Collier TK, Scholz NL, Incardona JP (2008) Fish embryos are damaged by dissolved PAHs, not oil particles. Aquat Toxicol 88:121-127 
Carls MG, Rice SD, Hose JE (1999) Sensitivity of fish embryos to weathered crude oil: Part I Low-level exposure during incubation causes malformations, genetic damage, and mortality in larval pacific herring (Clupea pallasi). Environ Toxicol Chem 18:481-493

Chow, ESH, Cheng, SH (2003) Cadmium affects muscle type development and axon growth in zebrafish embryonic somitogenesis. Toxicol Sci 73:149-159

Denison MS, Heath-Pagliuso S (1998) The Ah receptor: A regulator of the biochemical and toxicological actions of structurally diverse chemicals. Bull Environ Contam Toxicol 61:557-568

Chloé de Perre C, Le Ménach K, Ibalot F, Parlanti E, Budzinski H (2013),Development of solid-phase microextraction to study dissolved organic matter - polycyclic aromatic hydrocarbon interactions in aquatic environment. Anal Chim Acta submitted

Devier M-H, Augagneur S, Budzinski H, Le Menach K, Mora P, Narbonne J-F, Garrigues P (2005) Oneyear monitoring survey of organic compounds (PAHs, PCBs, TBT), heavy metals and biomarkers in blue mussels from the Arcachon Bay, France. J Environ Monit 7:224-240

Dupree C, Ahrens A (2007) Polycyclic aromatic hydrocarbons in Auckland's aquatic environment: source concentrations and potential environmental risks. Prepared by NIWA for Auckland Regional Council Auckland Regional Council Technical Publication No 378

Elonen GE, Spehar RL, Holcombe GW, Johnson RD, Fernandez JD, Erickson RJ, Tietge JE, Cook PM (1998) Comparative toxicity of 2,3,7,8-tetrachlorodibenzo- $p$-dioxin to seven freshwater fish species during early life-stage development. Environ Toxicol Chem 17:472-483

Fairbairn E A, Bonthius J, Cherr G N (2012) Polycyclic aromatic hydrocarbons and dibutyl phthalate

Farwell A, Nero V, Croft M, Bal P, Dixon DG (2006) Modified Japanese medaka embryo-larval bioassay disrupt dorsal-ventral axis determination via the Wnt/ $\beta$-catenin signaling pathway in zebrafish embryos. Aquat Toxicol 124-125:188-196

Feng S, Cao Z, Wang X (2013) Role of aryl hydrocarbon receptor in cancer. Biochim Biophys Acta 1836:197-210

Geffard O, Geffard A, His E, Budzinski H (2003) Assessment of the bioavailability and toxicity of sediment-associated polycyclic aromatic hydrocarbons and heavy metals applied to Crassostrea gigas embryos and larvae. Mar Pollut Bull 46:481-490

Glatt H, Rost K, Frank H, Seidel A, Kollock R (2008) Detoxification of promutagenic aldehydes derived from methylpyrenes by human aldehyde dehydrogenases ALDH2 and ALDH3A1. Arch Biochem Biophys 477:196-205 
Hartmann A, Agurell E, Beevers C, Brendler-Schwaab S, Burlinson B, Clay P, Collins A, Smith A, Speit G, Thybaud V, Tice RR (2003) Recommendations for conducting the in vivo alkaline Comet assay. Mutagenesis 18.45-51

Hayashida Y, Kawamura T, Hori-e R, Yamashita I (2004) Retinoic acid and its receptors are required for expression of aryl hydrocarbon receptor mRNA and embryonic development of blood vessel and bone in the medaka fish, Oryzias latipes. Zool Sci 21:541-51

He C, Zuo Z, Shi X, Li R, Chen D, Huang X, Chen Y,Wang C (2011) Effects of benzo(a)pyrene on the skeletal development of Sebastiscus marmoratus embryos and the molecular mechanism involved. Aquat Toxicol 101:335-341

Heister K, Pols S, Gustav Loch JP, Bosma TNP (2013) Desorption behaviour of polycyclic aromatic hydrocarbons after long-term storage of two harbour sludges from the port of Rotterdam, The Netherlands. J Soils Sed 13:1113-1122

Hendon LA, Carlson EA, Manning S, Brouwer M (2008) Molecular and developmental effects of exposure to pyrene in the early life-stages of Cyprinodon variegates. Comp Biochem Physiol C -

Ineris (2006) PAHs - Techno-economic data on chemical substances in France (HAP - Données technico- 
1 Kimbrough KL, Dickhut RM (2006) Assessment of polycyclic aromatic hydrocarbon input to urban wetlands in relation to adjacent land use. Mar Pollut Bull 52:1355-1363

Kocan RM, Matta MB, Salazar SM (1996) Toxicity of weathered coal tar for shortnose sturgeon (Acipenser brevirostrum) embryos and larvae. Arch Environ Contam Toxicol 31:161-165

Krasnov A, Koskinen H, Rexroad C, Afanasyev S, Molsa H, Oikari A (2005) Transcriptome responses to carbon tetrachloride and pyrene in the kidney and liver of juvenile rainbow trout (Oncorhynchus mykiss). Aquat Toxicol 74:70-81

Kumaravel TS, Vilhar B, Faux SP, Jha AN (2009) Comet Assay measurements: a perspective. Cell Biol Toxicol 25:53-64

L'Allemain G (2006) Role of the Wnt pathway in oncogenesis (Rôle des voies Wnt dans l'oncogénèse). Bull Cancer 93:88-97

Lee K-H, Li M, Michalowski AM, Zhang X, Liao H, Chen L, Xu Y, Wu X, Huang J (2010) A genomewide study identifies the Wnt signaling pathway as a major target of p53 in murine embryonic stem cells. Proc Natl Acad Sci 107(1):69-74

Letellier M, Budzinski H, Bellocq J, Connan J (1999) Focused microwave-assisted extraction of polycyclic aromatic hydrocarbons and alkanes from sediments and source rocks. Org Geochem 30:1353-1365

Li R, Zuo Z, Chen D, He C, Chen R, Chen Y, Wang C (2011) Inhibition by polycyclic aromatic hydrocarbons of ATPase activities in Sebastiscus marmoratus larvae: Relationship with the

Liehr GA, Heise S, Ahlf W, Offermann K, Witt G (2013) Assessing the risk of a 50-year-old dump site in the Baltic Sea by combining chemical analysis, bioaccumulation, and ecotoxicity. J Soils Sed 13:12701283

Lijoy MK, Simonich MT, Tanguay RL (2009) AHR-dependent misregulation of Wnt signaling disrupts tissue regeneration. Biochem Pharmacol 77(4):498-507

Livak KJ, Schmittgen TD (2001) Analysis of relative gene expression data using real-time quantitative

Long ER, Macdonald DD, Smith SL, Calder FD (1995) Incidence of adverse biological effects within ranges of chemical concentrations in marine and estuarine sediments. Environ Manage 19:81-97

MacDonald DD, Ingersoll CG, Berger TA (2000) Development and evaluation of consensus-based sediment quality guidelines for freshwater ecosystems. Arch Environ Contam Toxicol 39:20-31

MacDonald DD, Carr RS, Calder FD, Long ER, Ingersoll CG (1996) Development and evaluation of sediment quality guidelines for Florida coastal waters. Ecotoxicology 5:253-278 
1 Mhadhbi L, Boumaiza M, Beiras R (2010) A standard ecotoxicological bioassay using early life stages of the marine fish Psetta maxima. Aquat Living Resour 23:209-216

Monien BH, Müller C, Engst W, Frank H, Seidel A, Glatt H (2008) Time course of hepatic 1methylpyrene DNA adducts in rats determined by isotope dilution LC-MS/MS and ${ }^{32} \mathrm{P}-$ Postlabeling. Chem Res Toxicol 21:2017-2025

Morel Y, Mermod N, Barouki R (1999) An autoregulatory loop controlling CYP1A1 gene expression: Role of $\mathrm{H}_{2} \mathrm{O}_{2}$ and NFI. Mol Cell Biol 19:6825-6832

Morin B, Filatreau J, Vicquelin L, Barjhoux I, Guinel S, Leray-Forget J, Cachot J (2011) Detection of DNA damage in yolk-sac larvae of the Japanese Medaka, Oryzias latipes, by the comet assay. Anal Bioanal Chem 399:2235-2242

Münsterberg AE, Kitajewski J, Bumcrot DA, McMahon AP, Lassar AB (1995) Combinatorial signaling by Sonic hedgehog and Wnt family members induces myogenic bHLH gene expression in the somite. Genes Dev 9:2911-2922

Nagy AS, Simon G, Szabo J, Vass I (2013) Polycyclic aromatic hydrocarbons in surface water and bed

Notar M, Leskovsek H, Faganeli J (2001) Composition, distribution and sources of polycyclic aromatic hydrocarbons in sediments of the Gulf of Trieste, northern Adriatic Sea. Mar Pollut Bull 42:36-44

Novak J, Benisek M, Hilscherova K (2008) Disruption of retinoid transport, metabolism and signaling by environmental pollutants. Environ Int 34:898-913

Olive PL, Banath JP (1995) Sizing highly fragmented DNA in individual apoptotic cells using the comet assay and a DNA crosslink. Agent Exp Cell Res 221:19-26

Pancirov RJ, Brown RA (1977) Polynuclear aromatic hydrocarbons in marine tissues. Environ Sci Technol 11:989-992

Petersen GI, Kristensen P (1998) Bioaccumulation of lipophilic substances in fish early life stages. Environ Toxicol Chem 17:1385-1395

Pillai MC, Vines CA, Wikramanayake AH, Cherr GN (2003) Polycyclic aromatic hydrocarbons disrupt

Polakis P (2000) Wnt signaling and cancer. Genes Dev 14:1837-1851

Rhodes S, Farwell A, Hewitt LM, MacKinnon M, Dixon DG (2005) The effects of dimethylated and alkylated polycyclic aromatic hydrocarbons on the embryonic development of the Japanese medaka. 
Rolland RM (2000) A review of chemically-induced alterations in thyroid and vitamin A status from field studies of wildlife and fish. J Wild Dis 36:615-635

Sanchez-Avila J, Vicente J, Echavarri-Erasun B, Porte C, Tauler R, Lacorte S (2013) Sources, fluxes and risk of organic micropollutants to the Cantabrian Sea (Spain). Mar Pollut Bull 72:119-132

Schmidt CK, Hoegberg P, Fletcher N, Nilsson CB, Trossvik C, Hakansson H, Nau H (2003) 2,3,7,8Tetrachlorodibenzo-p-dioxin (TCDD) alters the endogenous metabolism of all-trans-retinoic acid in the rat. Arch Toxicol 77:371-383

Shimada T (2006) Xenobiotic-metabolizing enzymes involved in activation and detoxification of carcinogenic polycyclic aromatic hydrocarbons. Drug Metab Pharmacokinet 21:257-276

Teraoka H, Dong W, Okuhara Y, Lwasa H, Shindo A, Hill AJ, Kawakami A, Hiraga T (2006) Impairment of lower jaw growth in developing zebrafish exposed to 2,3,7,8-tetrachlorodibenzo- $p$ dioxin and reduced hedgehog expression. Aquat Toxicol 78:103-113

Teraoka H, Dong W, Ogawa S, Tsukiyama S, Okuhara Y, Niiyama M, Ueno N, Peterson RE, Hiraga T (2002) 2,3,7,8-tetrachlorodibenzo-p-dioxin toxicity in the zebrafish embryo: Altered regional blood flow and impaired lower jaw development. Toxicol Sci 65:192-199

Turcotte D, Akhtar P, Bowerman M, Kiparissis Y, Brown RS, Hodson PV (2011) Measuring the toxicity of alkyl-phenanthrenes to early life stages of medaka (Oryzias latipes) using partition-controlled delivery. Environ Toxicol Chem 30:487-495

Ulloa F, Marti E (2010) Wnt Won the War: Antagonistic Role of Wnt over Shh Controls Dorso-Ventral Patterning of the Vertebrate Neural Tube. Dev Dynam 239:69-76

Vicquelin L, Leray-Forget J, Peluhet L, LeMenach K, Deflandre B, Anschutz P, Etcheber H, Morin B, Budzinski H, Cachot J (2011) A new spiked sediment assay using embryos of the Japanese medaka specifically designed for a reliable toxicity assessment of hydrophobic chemicals. Aquat Toxicol $105: 235-245$

Wang X-C, Zhang Y-X, Chen RF (2001) Distribution and partitioning of polycyclic aromatic hydrocarbons (PAHs) in different size fractions in sediments from Boston harbor, United States. Mar Pollut Bull 42:1139-1149Wessel N, Santos R, Menard D, Le Menach K, Buchet V, Lebayon N, Loizeau V, Burgeot T, Budzinski H, Akcha F (2010) Relationship between PAH biotransformation as measured by biliary metabolites and EROD activity, and genotoxicity in juveniles of sole (Solea solea). Mar Environ Res 69:S71-S3 


\section{Figure captions}

$4 \quad$ Fig. 1 Total body length (grey bars) and head size (white bars) of medaka larvae at hatching following exposure to Pyr- or MePyr-spiked sediments. Values represent the mean response ( \pm SD) from three replicates. Different letters indicate significant differences between treatments using one-way ANOVA followed by Tukey's post-hoc test $(p<0.05 ; \mathrm{df}=4)$

9 Fig. 2 Developmental abnormalities in newly hatched larvae following Pyr or MePyr exposure. Values represent the mean response $( \pm \mathrm{SD})$ for three replicates. Statistical analysis was performed on each endpoint independently. Asterisks indicate significant differences in comparison with the control according to the results of one-way ANOVA followed by Tukey's post-hoc test $(p<0.05 ; \mathrm{df}=4)$ or nonparametric Kruskall-Wallis ANOVA followed by Bonferroni-Dunn's post-hoc test $(p<0.05 ; \mathrm{df}=4)$ for craniofacial deformities

Fig. 3 DNA damage in 2 dph-larvae following exposure of medaka embryos to Pyr- or MePyr-spiked sediments assessed with the comet assay. Values represent the mean response $( \pm \mathrm{SD})$ from three replicates for the percentage of Tail DNA (grey bars) and of hedgehog cells (white bars). Different letters indicate significant differences between treatments using one-way ANOVA followed by Tukey's posthoc test $(p<0.05 ; \mathrm{df}=4)$ 
Fig. 1

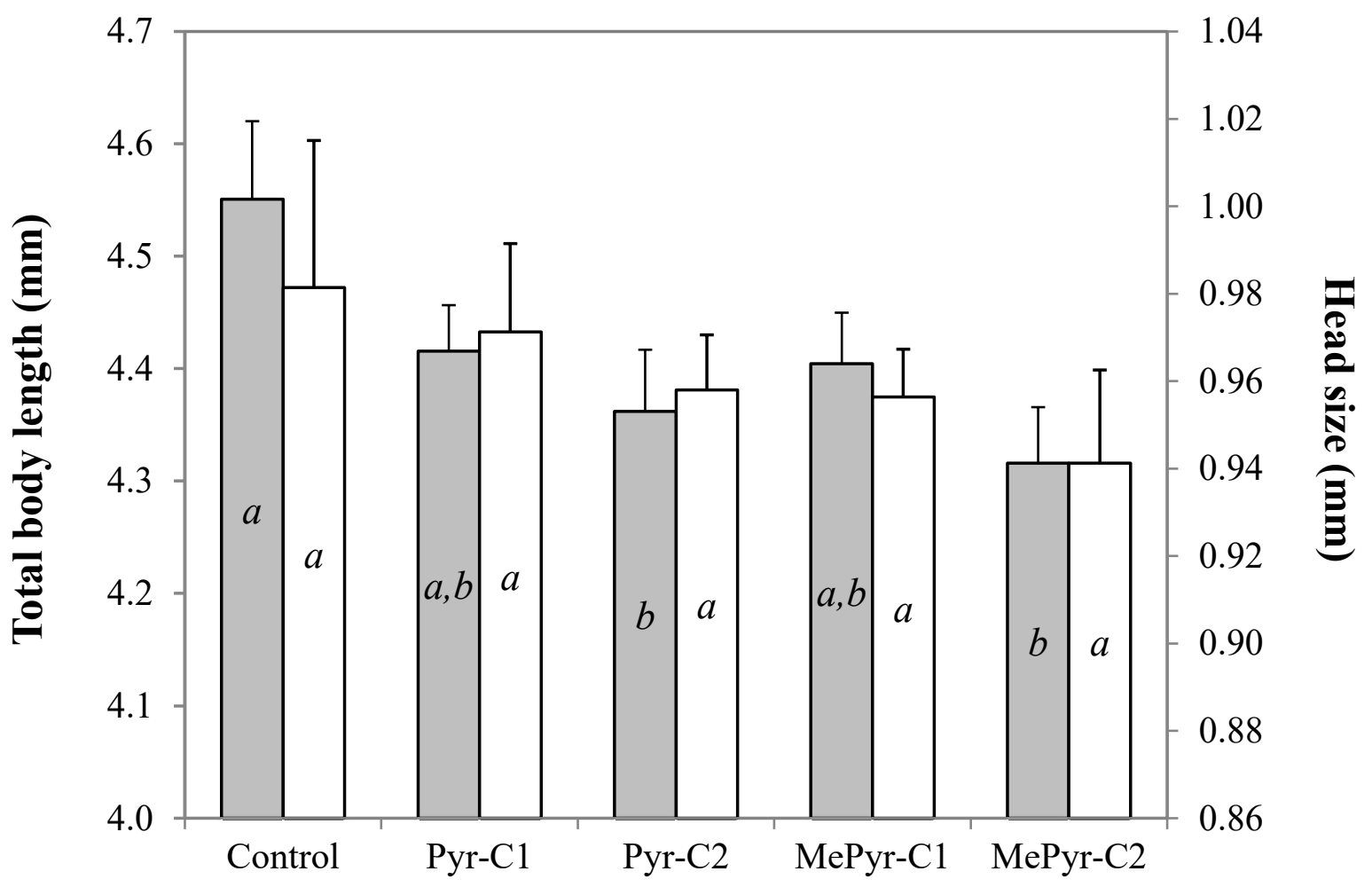


Fig. 2

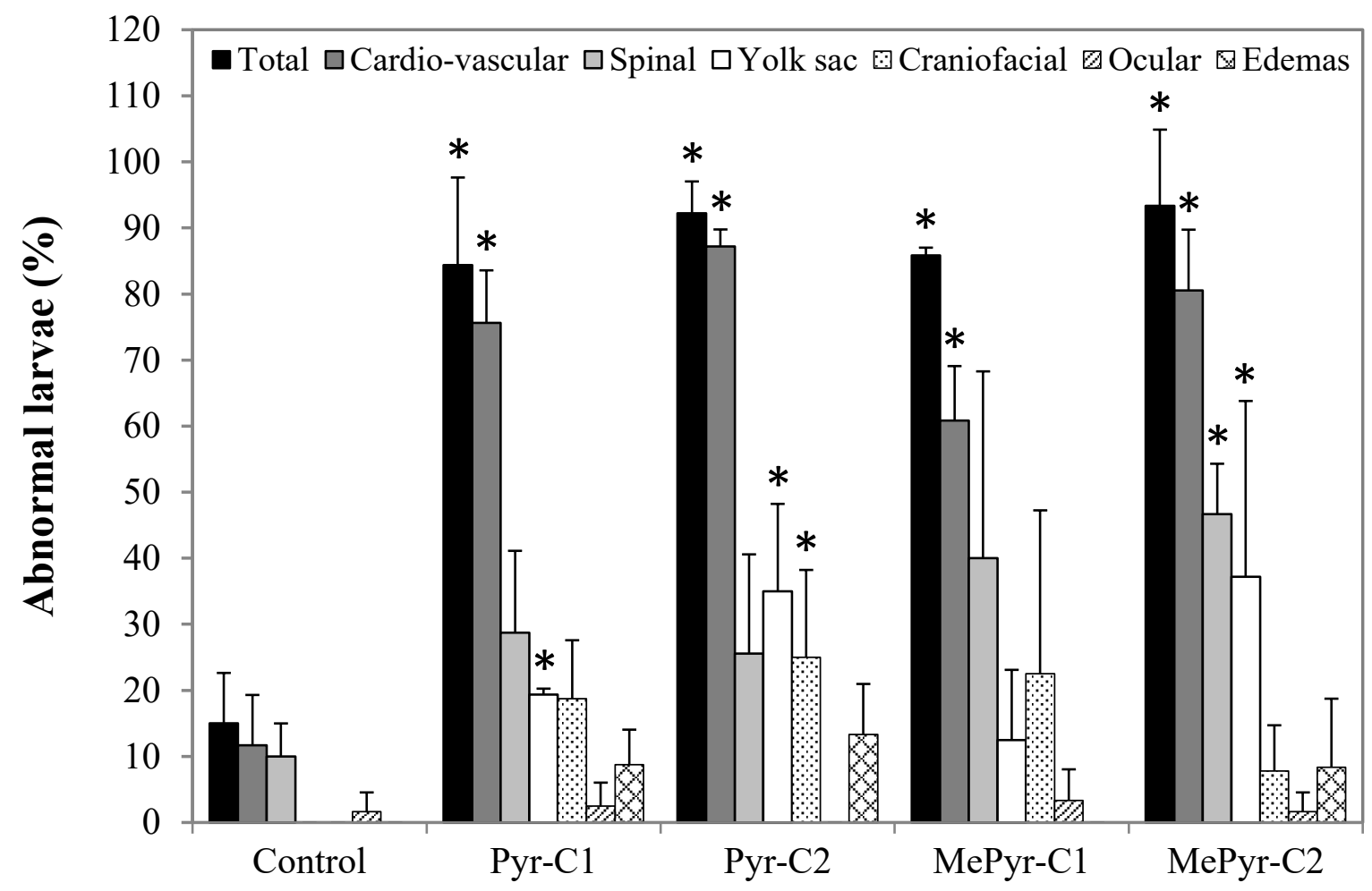


Fig. 3

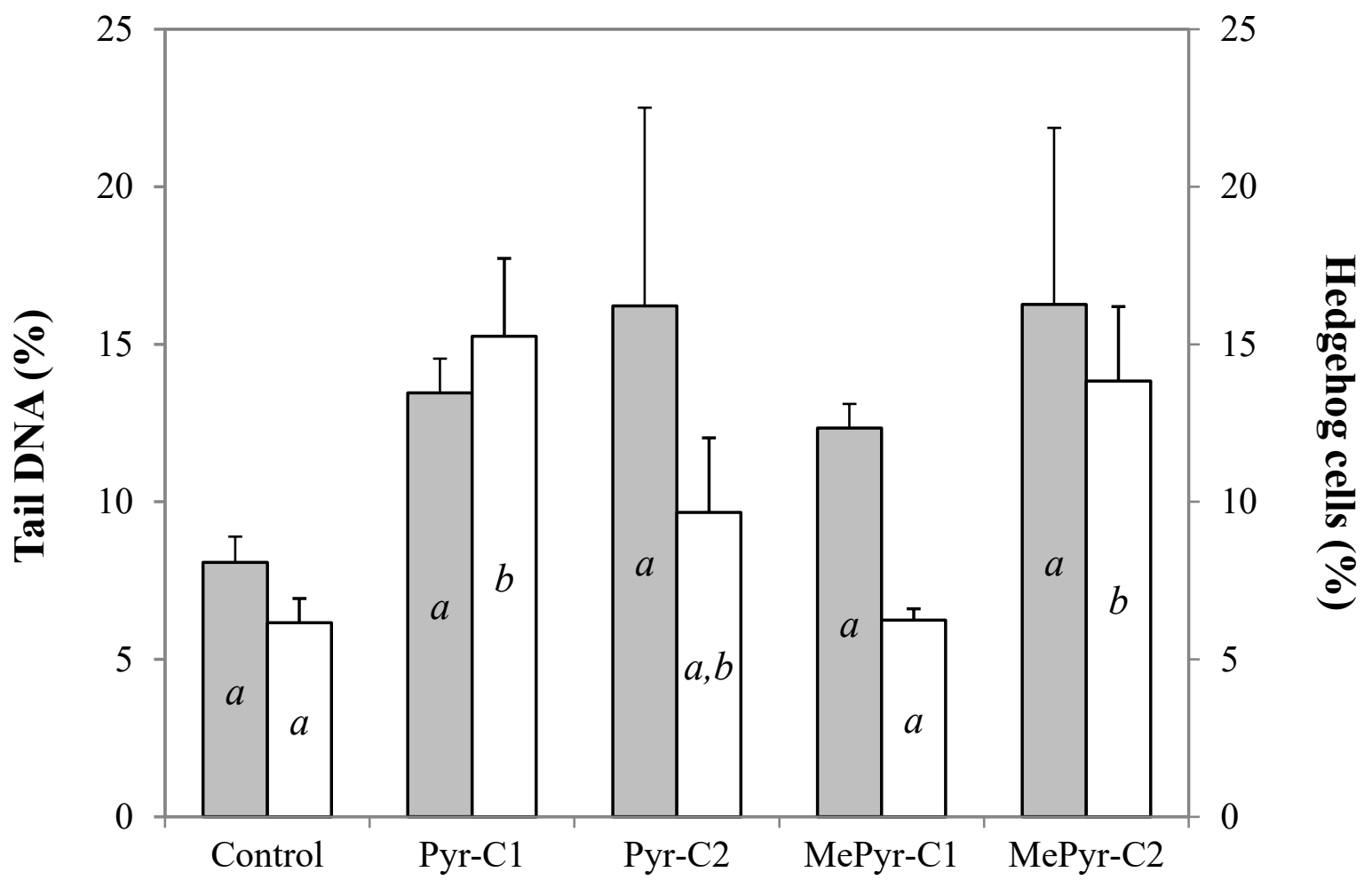




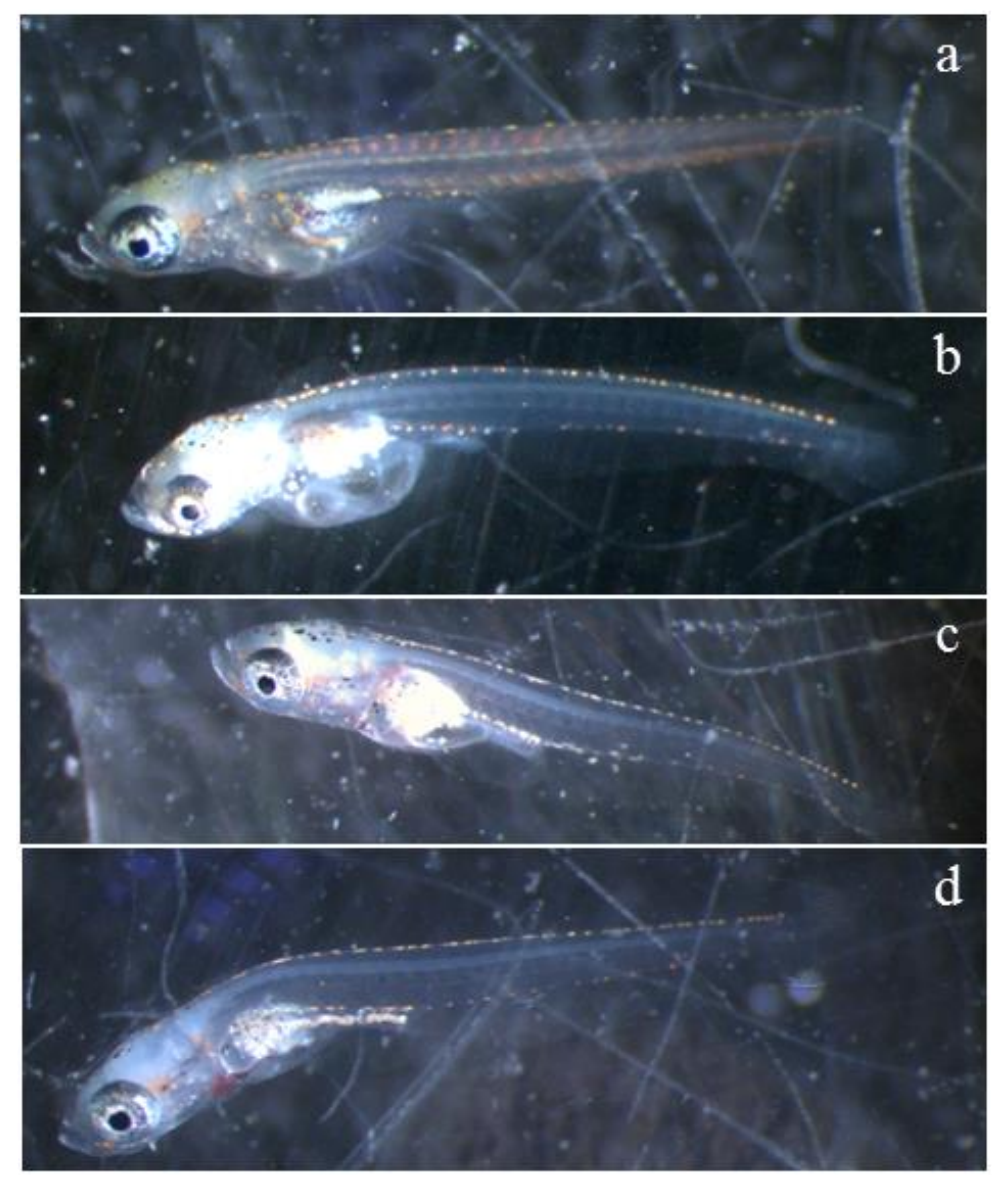

Fig. X. Examples of spinal deformities observed in newly hatched larvae following Pyr or MePyr exposure. (a) normal larvae from control treatment; (b) C-shaped larvae following Pyr-C1 exposure; larvae showing lordosis- (c) and kyphosis (d) -type deformities following MePyr-C2 exposure. 
Table 1. Sediment quality guidelines for Pyr in coastal and freshwater sediments and examples of Pyr contamination in sediments for moderately and highly impacted sites

\begin{tabular}{|c|c|c|}
\hline Sediment quality guideline/Sampling site & $\begin{array}{l}\text { Pyrene concentration } \\
\qquad(\mathrm{ng} / \mathrm{g} \mathrm{dw})\end{array}$ & Reference \\
\hline ERL (Effect range low) & 665 & Long et al., 1995 \\
\hline ERM (Effect range medium) & 2,600 & Long et al., 1995 \\
\hline TEL (Threshold effects level) & 153 & MacDonald et al., 1996 \\
\hline PEL (Probable effect level) & 1,398 & MacDonald et al., 1996 \\
\hline $\begin{array}{l}\text { Consensus-based TEC (Threshold effect } \\
\text { concentration) }\end{array}$ & 195 & MacDonald et al., 2000 \\
\hline $\begin{array}{l}\text { Consensus-based PEC (Probable effect } \\
\text { concentration) }\end{array}$ & 1,520 & MacDonald et al., 2000 \\
\hline Island End River (Boston harbor, USA) & $10,548-42,600^{a}$ & Wang et al., 2001 \\
\hline $\begin{array}{l}\text { Fort Point Channel (Boston harbor, } \\
\text { USA) }\end{array}$ & $1,258-10,042^{a}$ & Wang et al., 2001 \\
\hline Mystic River (Boston harbor, USA) & $1,694-7,045^{\mathrm{a}}$ & Wang et al., 2001 \\
\hline $\begin{array}{l}\text { Industrial discharge area (Cantabrian sea, } \\
\text { Spain) }\end{array}$ & 3,723 & Sanchez-Avila et al., 2013 \\
\hline $\begin{array}{l}\text { San Vicente de la Barqueira (Cantabrian } \\
\text { Sea, Spain) }\end{array}$ & 319 & Sanchez-Avila et al., 2013 \\
\hline Urdaibai (Cantabrian Sea, Spain) & 225 & Sanchez-Avila et al., 2013 \\
\hline $\begin{array}{l}\text { Beerkanaal (port of Rotterdam, the } \\
\text { Nederlands) }\end{array}$ & 1,130 & Heister et al., 2013 \\
\hline $\begin{array}{l}\text { Beneden Merwede River (port of } \\
\text { Rotterdam, the Nederlands) }\end{array}$ & 200 & Heister et al., 2013 \\
\hline $\begin{array}{l}\text { Mecklenburg Bight dump site (western } \\
\text { Baltic Sea, Germany) }\end{array}$ & $224-814^{b}$ & Liehr et al., 2013 \\
\hline Oissel (Seine estuary, France) & 1,418 & Cachot et al., 2006 \\
\hline La Bouille (Seine estuary, France) & $361-532$ & Cachot et al., 2006 \\
\hline Le Havre (Seine estuary, France) & 215 & Cachot et al., 2006 \\
\hline
\end{tabular}

a, concentration range measured in different grain size fractions of sediment; $b$, concentration range measured between 2002 and 2004 at the same sampling site. 
Table 2. Physico-chemical characteristics of the reference sediment (freeze-dried)

Yville-sur-Seine sediment (Seine-Maritime, Haute-Normandie, France)

Particulate organic carbon

$0.14 \%$

Dissolved ammonia $\left(\mathrm{NH}_{4}^{+}\right)^{\mathrm{a}}$

$40.7 \mu \mathrm{M}$

Dissolved sulfur $\left(\mathrm{H}_{2} \mathrm{~S}\right)^{\mathrm{a}}$

$17.6 \mu \mathrm{M}$

Grain size distribution

$10^{\text {th }}$ percentile diameter

$41.3 \mu \mathrm{m}$

$50^{\text {th }}$ percentile diameter

$230 \mu \mathrm{m}$

$90^{\text {th }}$ percentile diameter

$391 \mu \mathrm{m}$

$\leq 65 \mu \mathrm{m}$ fraction

$15.8 \%$

Trace metals levels $(\mu g / g d w)$

$\begin{array}{cccccccccc}\mathrm{Co} & \mathrm{Mn} & \mathrm{Ni} & \mathrm{Zn} & \mathrm{Cr} & \mathrm{As} & \mathrm{Ag} & \mathrm{Pb} & \mathrm{Cd} & \mathrm{Cu} \\ 0.74 & 8.0 & 1.0 & 7.3 & 1.74 & 0.33 & 0.01 & 12.5 & 0.02 & 1.09\end{array}$

Organic compounds levels $(n g / g d w)$

$\Sigma \mathrm{PAH}^{\mathrm{b}}$

$\Sigma \mathrm{PCB}^{\mathrm{c}}$

0.7

$\Sigma \mathrm{PBDE}^{\mathrm{d}}$

Not detected

$\Sigma \mathrm{OCP}^{\mathrm{e}}$

0.1

a, measurements performed on remoistened freeze-dried sediment

b, cumulative concentration of 21 analyzed polycyclic aromatic hydrocarbon compounds

c, cumulative concentration of 8 analyzed polychlorobiphenyl congeners

$\mathrm{d}$, cumulative concentration of 4 analyzed polybrominated diphenylethers

e, cumulative concentration of 16 analyzed organochlorine pesticides 
Table 3. Accession number and sequence of primer pairs for the thirteen $O$. latipes genes used in the present study

\begin{tabular}{|c|c|c|c|}
\hline Gene & Function & $\begin{array}{l}\text { Accession number } \\
\text { (EMBL or GenBank) }\end{array}$ & Primers sequences \\
\hline$\beta$-actin & $\begin{array}{l}\text { Cytoskeletal gene } \\
\text { (housekeeping gene) }\end{array}$ & S74868 & $\begin{array}{l}\text { GTGACCCACACAGTGCC }^{\mathrm{a}} \\
\text { GCGACGTAGCACAGCTTC }^{\mathrm{b}}\end{array}$ \\
\hline$r p l 7$ & $\begin{array}{l}\text { Ribosomal protein L7 } \\
\text { (housekeeping gene) }\end{array}$ & NM_001104870 & $\begin{array}{l}\text { AACGTGGCTACGGCAG } \\
\text { CGAGGTGACGACAGCTT }^{\mathrm{b}}\end{array}$ \\
\hline $\operatorname{cox} I$ & $\begin{array}{l}\text { Cytochrome c oxidase subunit I } \\
\text { (complex IV of the mitochondrial } \\
\text { respiratory channel) }\end{array}$ & $\begin{array}{l}\text { NC_004387 (gene ID } \\
805432)\end{array}$ & $\begin{array}{l}\text { TTCCCCCAACACTTCTTAGGC }^{\mathrm{a}} \\
\text { TGTGGCTGTTAGTTCGACTGA }^{\mathrm{b}}\end{array}$ \\
\hline p53 & Tumor suppressor gene P53 & AF212997 & $\begin{array}{l}\text { TCTGGCACTGCAAAGTCTGT } \\
\text { CCTCGTTTTGGTGGTGGG }^{\mathrm{b}}\end{array}$ \\
\hline cypla & Cytochrome P450 1A & AY297923 & $\begin{array}{l}\text { CTCCCTTTCACAATTCCACACT } \\
\text { TGCAACGCCGCTTTCC }^{\mathrm{b}}\end{array}$ \\
\hline wntl & $\begin{array}{l}\text { Wingless integration site } 1 \\
\text { (cell proliferation and somitogenesis) }\end{array}$ & AJ243208 & $\begin{array}{l}\text { CCGCTTTGACGGAGCAT }^{\mathrm{a}} \\
\text { TTGAACCCACGCCCACAGC }^{\mathrm{b}}\end{array}$ \\
\hline $\operatorname{sod}(M n)$ & $\begin{array}{l}\text { Mitochondrial Fe/Mn superoxide } \\
\text { dismutase }\end{array}$ & ENSORLG00000013261 & $\begin{array}{l}\text { ATGGCTGGGCTATGACAAAG }^{\mathrm{a}} \\
\text { TGGCTATCTGAAGACGCTCAC }^{\mathrm{b}}\end{array}$ \\
\hline $\operatorname{sod}(\mathrm{Cu} / \mathrm{Zn})$ & Cytosolic $\mathrm{Cu} / \mathrm{Zn}$ superoxide dismutase & ENSORLG00000008041 & $\begin{array}{l}\text { GGGAAATGTGACCGCAGG } \\
\text { GCCAAACGCGCTCCAG }^{\mathrm{b}}\end{array}$ \\
\hline bax & Bcl-2 associated $\mathrm{X}$ protein gene & ENSORLG0000000456 & $\begin{array}{l}\text { TCTTCGCTCAGTCCCTCC } \\
\text { GCCAACGTCTGCCAGCCA }^{\mathrm{b}}\end{array}$ \\
\hline $\operatorname{ogg} 1$ & $\begin{array}{l}\text { 8-oxoguanine glycosylase } 1 \text { gene } \\
\text { (BER family) }\end{array}$ & ENSORLG00000010758 & $\begin{array}{l}\text { CTCGTATTCAGGGCATGGT } \\
\text { ACCCGTGGCTGTCTAAG }\end{array}$ \\
\hline raldh2 & Retinaldehyde dehydrogenase type 2 & NM_001104821 & $\begin{array}{l}\text { GCCGCTCACCTGTCTCTAT }^{\mathrm{a}} \\
\text { TCCCTGCCGCCTCTTG }^{\mathrm{b}}\end{array}$ \\
\hline raral & Retinoic acid receptor alpha 1 & EF546452 & $\begin{array}{l}\text { GCATCATCAAGACGGTGGAG }^{\mathrm{a}} \\
\text { GGCGAAAGCGAAAACCAGG }^{\mathrm{b}}\end{array}$ \\
\hline raryl & Retinoic acid receptor gamma 1 & EF546454 & $\begin{array}{l}\text { CTCGTGTCTACAAACCCTGC } \\
\text { ATGCCGACCTCGAAGC }^{\mathrm{a}}\end{array}$ \\
\hline $\operatorname{rxr\alpha l}$ & Retinoid X receptor alpha 1 & EF537036 & $\begin{array}{l}\text { GGGTGCCTTCGAGCCA }^{\mathrm{a}} \\
\text { CCGGTAACCGCAGCAACAGT }^{\mathrm{b}}\end{array}$ \\
\hline
\end{tabular}

a, upstream primer; $b$, forward primer 
Table 4. Pyr and MePyr concentrations in spiked sediments and ERS buffer at T0- (beginning of exposure), T7(7 dpf) and T9- (9 dpf) sampling times.

\begin{tabular}{|c|c|c|c|c|c|c|c|c|}
\hline \multirow{2}{*}{ Condition } & \multicolumn{3}{|c|}{ Pyrene } & \multicolumn{3}{|c|}{ Methylpyrene } & \multirow{2}{*}{$\begin{array}{c}\text { Nominal } \\
\text { concentration }\end{array}$} & \multirow{2}{*}{$\begin{array}{c}\text { Spiking } \\
\text { efficiency }(\%)^{*}\end{array}$} \\
\hline & T0 & $\mathrm{T} 7$ & T9 & T0 & $\mathrm{T} 7$ & T9 & & \\
\hline \multicolumn{9}{|c|}{ Concentration in sediment $(n g / g d w)$} \\
\hline Control & $<0.1$ & - & - & $<0.1$ & - & - & 0 & \\
\hline Pyr-C1 & 250 & - & - & $<0.1$ & - & - & 300 & 82.8 \\
\hline Pyr-C2 & 2,770 & - & - & $<0.1$ & - & - & 3,000 & 92.1 \\
\hline MePyr-C1 & 62 & - & - & 202 & - & - & 300 & 69.7 \\
\hline MePyr-C2 & $<0.1$ & - & - & 2,586 & - & - & 3,000 & 87.8 \\
\hline \multicolumn{9}{|c|}{ Concentration in ERS buffer $(n g / L)$} \\
\hline Control & 1.48 & 12.5 & 3.17 & 0.16 & 0.39 & 3.50 & & \\
\hline Pyr-C1 & - & 204 & 629 & - & 0.12 & 1.17 & & \\
\hline Pyr-C2 & - & 2,488 & 3,125 & - & 0.19 & 1.10 & & \\
\hline MePyr-C1 & - & 8.02 & 58.4 & - & 98.3 & 53.5 & & \\
\hline MePyr-C2 & - & 9.56 & 5.21 & - & 1,698 & 1,831 & & \\
\hline
\end{tabular}

* Spiking efficiency calculation was based on the exact amount of Pyr or MePyr introduced during the spiking procedure. 
Table 5. Embryonic survival, hatching success and time to hatch following medaka embryos exposure to Pyr or MePyr-spiked sediments

\begin{tabular}{cccc}
\hline Condition & Embryonic survival (\%) & Hatching success (\%) & Time to hatch (dpf) \\
\hline Control & $96.7 \pm 2.24^{\mathrm{a}}$ & $87.0 \pm 8.74^{\mathrm{a}}$ & $9.50 \pm 0.26^{\mathrm{a}}$ \\
Pyr-C1 & $94.0 \pm 4.40^{\mathrm{a}, \mathrm{b}}$ & $77.2 \pm 1.04^{\mathrm{a}, \mathrm{b}}$ & $9.82 \pm 0.01^{\mathrm{a}, \mathrm{b}}$ \\
Pyr-C2 & $91.6 \pm 1.33^{\mathrm{b}}$ & $71.4 \pm 14.4^{\mathrm{a}, \mathrm{b}}$ & $9.87 \pm 0.57^{\mathrm{a}, \mathrm{b}}$ \\
MePyr-C1 & $96.0 \pm 2.35^{\mathrm{a}, \mathrm{b}}$ & $46.1 \pm 17.0^{\mathrm{b}}$ & $10.8 \pm 0.39^{\mathrm{b}}$ \\
MePyr-C2 & $95.6 \pm 2.58^{\mathrm{a}, \mathrm{b}}$ & $80.3 \pm 12.1^{\mathrm{a}, \mathrm{b}}$ & $9.70 \pm 0.1144^{\mathrm{a}, \mathrm{b}}$ \\
\hline
\end{tabular}

Values represent the mean responses $( \pm S D)$ from six replicates for embryonic survival and from three replicates for hatching success and time to hatch. For time to hatch calculations, the hatching day of unhatched embryos at the end of experiment was set at $12 \mathrm{dpf}$. Different letters indicate significant differences between treatments using one-way ANOVA followed by Tukey's post-hoc test $(p<0.05$; degree of freedom $(\mathrm{df})=4)$. 
Table 6. Variations in differential gene transcription levels as compared to control observed in medaka embryos (T7) and larvae (T9) after exposure to Pyr- or MePyr-spiked sediments

\begin{tabular}{|c|c|c|c|c|c|c|c|c|c|c|c|c|}
\hline & \multirow{2}{*}{$\frac{\begin{array}{c}\text { Mitochondrial } \\
\text { metabolism }\end{array}}{\operatorname{cox} I}$} & \multirow{2}{*}{$\frac{\begin{array}{c}\text { Xenobiotic } \\
\text { metabolism }\end{array}}{\text { cypla }}$} & \multicolumn{2}{|c|}{$\begin{array}{c}\text { Oxidative stress } \\
\text { defense }\end{array}$} & \multicolumn{2}{|c|}{$\begin{array}{l}\text { Cell cycle } \\
\text { arrest/ } \\
\text { apoptosis }\end{array}$} & \multirow{2}{*}{$\begin{array}{c}\begin{array}{c}\text { Development/ } \\
\text { embryo- } \\
\text { genesis }\end{array} \\
w n t 1\end{array}$} & \multirow{2}{*}{$\begin{array}{l}\text { DNA } \\
\text { repair } \\
\text { oggl }\end{array}$} & \multicolumn{4}{|c|}{ Retinoid metabolism } \\
\hline & & & $\operatorname{sod}(M n)$ & $\operatorname{sod}(\mathrm{Cu} / \mathrm{Zn})$ & p53 & $\operatorname{bax}$ & & & raldh2 & raral & $\operatorname{rar} \gamma 1$ & rxral \\
\hline \multicolumn{13}{|c|}{ Embryonic stage (T7) } \\
\hline Pyr-C1 & 1.1 & 1.0 & 1.0 & 0.9 & 1.1 & 0.8 & 1.0 & 0.9 & 0.8 & 1.3 & 0.8 & 1.1 \\
\hline Pyr-C2 & $1.5^{*}$ & $1.8^{*}$ & 1.1 & 1.0 & 1.2 & 1.4 & 1.8 & 1.2 & 0.8 & 1.5 & 1.0 & $2.0^{\mathrm{a}}$ \\
\hline MePyr-C1 & $1.4^{*}$ & 1.1 & 1.1 & 1.0 & 1.4 & 0.9 & 0.8 & 1.0 & 0.7 & 1.4 & 0.8 & 1.5 \\
\hline MePyr-C2 & $1.7 *$ & $2.5^{*}$ & 1.1 & 1.0 & 1.3 & 1.1 & 1.7 & 2.1 & 1.0 & $1.8^{*}$ & 1.1 & 2.0 \\
\hline \multicolumn{13}{|c|}{ Larval stage (T9) } \\
\hline Pyr-C1 & 0.9 & 1.7 & 1.1 & 0.8 & 1.4 & 0.9 & $2.6^{*}$ & 1.1 & 1.4 & 1.5 & 1.0 & 1.2 \\
\hline Pyr-C2 & 0.8 & $2.0^{b}$ & 0.9 & 0.8 & 1.3 & 0.9 & 1.6 & 1.3 & 1.0 & 1.4 & 0.9 & 1.2 \\
\hline MePyr-C1 & 0.9 & 1.4 & 0.9 & 0.8 & $1.6^{*}$ & 0.9 & $2.9 *$ & $1.2 *$ & 1.2 & $1.7 *$ & 1.1 & $1.4^{d}$ \\
\hline MePyr-C2 & 0.9 & 1.2 & 1.1 & 0.9 & $2.0 *$ & 1.1 & $3.0 *$ & $1.9^{c}$ & $1.4^{*}$ & $2.0 *$ & 1.2 & 1.5 \\
\hline
\end{tabular}

Results are mentioned as control-relative gene induction $(>1)$ or repression $(<1)$ factors. The $*$ sign indicates a significant difference in comparison to the control, according to $t$ test for independent samples $(p<0.05 ; \mathrm{df}=4)$. a, $p=0.069 ; \mathrm{b}, p=0.076 ; \mathrm{c}, p=0.054 ; \mathrm{d}, p=0.078$. 